Sattoe, J.N.T., Bal, M.I., Roelofs, P.D.D.M., Bal, R., Miedema, H.S., Staa, A. van. Self-management interventions for young people with chronic conditions: a systematic overview. Patient

\begin{tabular}{|l|l|}
$\begin{array}{l}\text { Postprint } \\
\text { Version }\end{array}$ & 1.0 \\
\hline Journal website & https://linkinghub.elsevier.com/retrieve/pii/S0738-3991(15)00095-6 \\
\hline Pubmed link & $\underline{\text { https://www.ncbi.nlm.nih.gov/pubmed/25819373 }}$ \\
\hline DOI & $10.1016 /$ j.pec.2015.03.004 \\
\hline
\end{tabular}

This is a NIVEL certified Post Print, more info at http://www.nivel.eu

\title{
Self-management interventions for young people with chronic conditions: A systematic overview
}

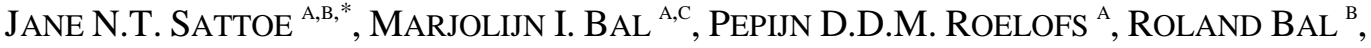 \\ HARALD S. MIEDEMA ${ }^{\text {A }}$, ANNELOES VAN STAA ${ }^{\mathrm{A}, \mathrm{B}}$ \\ ${ }^{a}$ Rotterdam University of Applied Sciences, Research Centre Innovations in Care, \\ Rotterdam, The Netherlands \\ ${ }^{\mathrm{b}}$ Erasmus University Rotterdam, Institute of Health Policy \& Management, Rotterdam, The \\ Netherlands \\ ${ }^{c}$ Erasmus Medical University, Department of Rehabilitation Medicine, Rotterdam, The \\ Netherlands
}

\section{Highlights}

- We provide a systematic overview of self-management interventions for chronically ill young people aged $7-25$ years.

- Interventions' content, formats, underlying theories and outcomes used in evaluation studies were reviewed.

- Most studies aimed at medical management and were unclear about theoretical bases, while formats and used outcomes varied.

- Our overview may assist professionals in determining the breadth and focus of the support they provide.

- We present a content-based evaluation framework that may help researchers to select measures for evaluation studies.

\footnotetext{
Abstract

Objective: To provide a systematic overview of self-management interventions (SMI) for young people with chronic conditions with respect to content, formats, theories, and evaluated outcomes.

Methods: Embase, Medline, PsycINFO, Web-of-Science, CINAHL, and Cochrane were searched. Reviews' reference lists were scrutinized. Selected studies were: Original research articles in English published between 2003 and March 2014; about the evaluation of SMI for 7 to 25-year-olds with somatic chronic conditions/physical disabilities; with clear outcomes and intervention descriptions. The classification of medical, role and emotion management served to review content. Formats, theories, and evaluated outcomes were summarized.

Results: 86 studies were reviewed. Most aimed at medical management and were unclear about theoretical bases. Although a variety of outcomes was
} 
Sattoe, J.N.T., Bal, M.I., Roelofs, P.D.D.M., Bal, R., Miedema, H.S., Staa, A. van. Self-management interventions for young people with chronic conditions: a systematic overview. Patient Education and Counseling: 2015, 98(6), 704-715

evaluated and the distribution over self-management domains was quite unpredictable, outcomes conceptually related to specific content. A contentbased framework for the evaluation of self-management interventions is presented.

Conclusions and practice implications: : SMI relate to self-management tasks and skill-building. Yet, conceptualizations of self-management support often remained unclear and content focuses predominantly on the medical domain, neglecting psycho-social challenges for chronically ill young people. Future evaluations should match outcomes/themes to content and characteristics. Our framework and overview of SMI characteristics and outcomes may assist clinicians in providing self-management support.

\section{INTRODUCTION}

Worldwide, the number of young people living with a chronic condition or with special health care needs is growing. In the USA, the 2009-2010 National Survey of Children with Special Health Care Needs showed that $15.1 \%$ of all under 17-yearsolds fell in this category [1]. In the Netherlands, the most recent estimations are 14\% of all under 18-year-olds [2] and $11 \%$ of all under 25-year-olds [3].

Chronic illness affects young people in many ways during their transition to adulthood and adult care [4,5]. Supporting them to develop independence and selfmanagement skills is therefore a key task of healthcare professionals. For that matter, self-management support is considered an integral part of healthcare for all people with chronic conditions [6-8]. The WHO definition of health was even redefined as "the ability to adapt and self-manage in the face of social, physical, and emotional challenges" [9].

Living with a chronic condition is an "ongoing process of inner negotiation" between social and medical needs [10] or what is described as shifting between the illness-onthe-foreground and wellness-on-the-foreground perspective [11]. Self-management therefore has been defined as "the individual's ability to manage the symptoms and the consequences of living with a chronic condition, including treatment, physical, social, and lifestyle changes" [12]. Note, however, that self-management is not restricted to one's individual ability, especially not in pediatrics where parents tend to play a key role. Adding the phrase "[...] in conjunction with family, community, and healthcare professionals [...]" [13] seems to present a more complete picture. This holistic view accounts for the three tasks involved in self-management: medical management (re. treatment), role management (re. social participation), and emotion or identity management (re. emotional consequences of being ill) [14]. Young people with chronic conditions have to learn these tasks, and in supporting them we must take their developmental transition into account [15].

Various self-management interventions (SMI) for the chronically ill are available, but their effectiveness is not clear [16,17]. This is even more pertinent to SMI in pediatric care $[16,18,19]$. Newman and colleagues [16] emphasize that a theorybased approach is needed to evaluate complex SMI, and recommend a more systematic comparison of different types of SMI [20]. Recent studies on SMI for people with chronic conditions in general $[17,21]$ and for young people with physical disabilities [19] endorse this view, and it is recommended to standardize SMI evaluation by using a core set of outcomes $[19,22]$. 
Sattoe, J.N.T., Bal, M.I., Roelofs, P.D.D.M., Bal, R., Miedema, H.S., Staa, A. van. Self-management interventions for young people with chronic conditions: a systematic overview. Patient Education and Counseling: 2015, 98(6), 704-715

We reviewed and systematically compared the characteristics and content of offered SMI for young people (7-25 years) with chronic conditions, their theoretical foundations, if any, and the evaluated outcomes. Based on the results we present content-related outcome measures for the evaluation of different types of selfmanagement interventions.

\section{METHODS}

\subsection{Study design}

A systematic overview, defined by Grant and Booth [23], as a "summary of the literature that attempts to survey the literature and describe it characteristics" was applied. This allows for a systematic comparison of SMI and outcome measures used in evaluation studies. Methodological characteristics according to the 'Search, Appraisal, Synthesis and Analysis' (SALSA) framework [23] are: comprehensive searching, quality assessment, narrative synthesis with tabular features, and thematic analysis. The review process was guided by the Preferred Reporting Items for Systematic Reviews and Meta-Analyses (PRISMA) statement [24].

\subsection{Search strategy}

The search strategy employed variations and Boolean connections (AND, OR) of the following terms: self-management, children, adolescents, young adults, chronic illness, and intervention. Relevant variations were derived from database thesauruses and relevant review articles (i.e. childhood, youth, chronic disease, physical disability, program etc.). Six health-related databases were searched: Embase, Medline, PsycINFO, Web-of-Science, CINAHL, and Cochrane. An information specialist helped define the final search strategies, employing a combination of freetext and thesaurus terms. The strategy used in Embase is presented in Box 1. Two researchers (JS, MB) supplemented the database searches by scrutinizing relevant reviews' references for additional relevant publications.

\section{[BOX 1]}

\subsection{Inclusion criteria}

- Study types: only original research articles in English language published from 2003 to March 2014. No restrictions were placed on study design.

- Participants: young people (aged 7-25 years) with somatic chronic conditions or physical disability.

- Interventions: studies focusing on the evaluation of an SMI and describing the SMI or referring to previous description(s) of the intervention.

- Outcome measures: No restrictions were placed on the type of outcome measures, as this was our main interest. However, outcome measures needed to be clearly defined.

Studies had to meet all inclusion criteria to be included for further analysis.

Furthermore, the term 'children' is used for young people aged 7-12 years, the term 'adolescents' is used for the age group of 13-18 years, and the term 'young adults' is used for those aged 19-25 years.

\subsection{Selection, quality assessment, and data extraction}

Retrieved records $(n=5908)$ were imported into Endnote ${ }^{\circledR}$. Two reviewers (JS, MB) independently selected eligible studies from both title and abstract and categorized 
Sattoe, J.N.T., Bal, M.I., Roelofs, P.D.D.M., Bal, R., Miedema, H.S., Staa, A. van. Self-management interventions for young people with chronic conditions: a systematic overview. Patient Education and Counseling: 2015, 98(6), 704-715

them into: include, exclude or not clear. Any discrepancies were resolved, and decisions were made on the 'not clear' category. Full texts of all agreed-upon articles $(n=444)$ were retrieved. The two reviewers decided on final inclusion of articles based on the full text, resulting in 103 publications. The selection process is presented in Fig. 1. Three reviewers (JS, MB, PR) assessed methodological quality of randomized controlled trials and cohort studies with methodology checklists of the Scottish Intercollegiate Guidelines Network (SIGN) [25]. For qualitative studies the 'Consolidated criteria for reporting qualitative research' (COREQ) checklist [26] was used. Any discrepancies were resolved by discussion. Seventeen studies were excluded because outcome measures were not clear, leaving 86 studies. Two reviewers (JS, MB) extracted data on study design, study sample, type and content of interventions, settings of interventions, interventionists, theoretical basis, and outcome measures. Data were recorded in an electronic extraction form.

\section{[FIGURE 1]}

\subsection{Analysis}

General study characteristics were summarized, i.e. study country, chronic conditions addressed and study designs, as well as SMI characteristics, i.e. the modes, formats, elements and settings of SMI and professionals involved. Lorig and Holman's classification of domains of self-management [14] served as a framework to review the content of SMI. Interventions could be aiming at medical management, role management, emotion management or a combination thereof. Further analysis included comparisons of theories underlying SMI per self-management domain. Finally, evaluated outcome measures were inventoried and linked to the content of SMI. On the premise that certain outcome measures logically relate to specific content of SMI, one reviewer (JS) linked all outcome measures to the content descriptions. Another reviewer (MB) checked this to enhance validity of this analysis.

\section{RESULTS}

\subsection{General study characteristics $(n=86)$}

- Countries: Most studies hailed from the USA $(n=51)$, followed by the Netherlands $(n=8)$, the UK $(n=7)$, Australia $(n=4)$, Canada $(n=3)$, Germany $(n=3)$, Hungary $(n=2)$, Taiwan $(n=2)$, Austria $(n=1)$, China $(n=1)$, Denmark $(n=1)$, France $(n=1)$, Haiti $(n=1)$, and Norway $(n=1)$.

- Chronic conditions: Most studies targeted asthma $(n=18)$, followed by diabetes $(n=16)$. Six studies targeted several chronic conditions (Table 1).

- Study designs: All but nine studies had fully quantitative study designs. Forty-five of them were randomized controlled trials, 29 were cohort studies and 3 were cross-sectional studies. Three studies had fully qualitative study designs, while five were mixed-methods studies and one was a case study. Twenty-six studies (30.2\%) were classified as pilot evaluations. 
Sattoe, J.N.T., Bal, M.I., Roelofs, P.D.D.M., Bal, R., Miedema, H.S., Staa, A. van. Self-management interventions for young people with chronic conditions: a systematic overview. Patient Education and Counseling: 2015, 98(6), 704-715

- Interventions: A total of 81 different interventions were reviewed, because different studies evaluated the same intervention with different outcome measures ([27] and [28]; [111] and [112]; [93] and [94] and [95]; [75] and [77].

[TABLE 1]

\subsection{Intervention characteristics $(n=81)$}

Interventions were either applied at individual level $(n=39 ; 48.1 \%)$, at group level $(n=34 ; 42.0 \%)$ or both $(n=8 ; 9.9 \%)$. Most interventions included educational and/or skills training sessions $(n=35 ; 43.2 \%)$ or telemedicine systems $(n=14$; $17.3 \%$ ). Intervention formats and elements are summarized in Table 2. In 20 interventions (24.7\%), parents were included as participants. These interventions often considered educational and/or skills training and most included both separate and joint sessions. Three interventions $(3.7 \%)$ offered joint sessions only, while seven interventions $(8.6 \%)$ offered separate but parallel sessions for parents and their children. Intervention settings were camping sites $(n=10 ; 12.4 \%)$, inpatient or outpatient clinics $(n=35 ; 43.2 \%)$, home or public environments $(n=13 ; 16.0 \%)$, school $(n=9 ; 11.1 \%)$, or online $(n=10 ; 12.4 \%)$. Settings were not exclusive for the formats of interventions. Four studies $(4.9 \%)$ did not detail the settings.

\section{[TABLE 2]}

Interventionists included pediatricians, nurses, physiotherapists, occupational therapists, psychologists, social workers, pedagogues, dietitians, job coaches, and speech pathologists. In some cases, interns or research assistants were additionally available. Occasionally, the whole healthcare team was involved. Twenty-two studies (27.2\%) lacked this information. See Appendix A for an overview of general study characteristics and intervention characteristics per study.

\subsection{Medical, role and emotion management: content of self-management interventions}

The content of interventions includes the actual themes, topics, issues or specific skills discussed, reviewed or practiced during the interventions. Content is categorized by the domains of self-management [12] in Table 3. Many interventions $(46.2 \%)$ were solely aimed at medical management; some considered role management $(6.4 \%)$ or emotion management $(2.6 \%)$ alone. Others addressed multiple domains, see Fig. 2.

\section{[TABLE 3][FIGURE 2]}

Medical management was either disease-specific or of a more general nature. The former refers to tasks or topics associated with or related to a specific diagnosis, e.g., self-monitoring of blood glucose values in diabetes. This type of content is not exchangeable between interventions, e.g., education on treatment of cystic fibrosis is not useful for renal transplant patients. General medical management refers to health and healthcare related tasks irrespective of diagnosis. For instance, accessing healthcare, but also child-parent sharing or teamwork related to medical management tasks. 
Sattoe, J.N.T., Bal, M.I., Roelofs, P.D.D.M., Bal, R., Miedema, H.S., Staa, A. van. Self-management interventions for young people with chronic conditions: a systematic overview. Patient Education and Counseling: 2015, 98(6), 704-715

Role management referred to tasks or topics on domains related to social participation, such as communicating, decision-making, assertiveness, and keeping up with peers. Domains are school, work, community, living, housing, recreation, sports and leisure, relationships and sexuality. A major focus is on peer relationships and disclosure of the condition in social environments.

Emotion (or identity) management referred to the young person's feelings and intrinsic characteristics. Topics covered are building self-confidence, developing a positive body image, self-appreciation, maintaining positive thinking, stress management, but also acceptance of the condition.

The content of interventions was not specifically linked to certain modes, formats, elements or settings of SMI. In general, interventionists were not exclusive for content of interventions, although occasionally specific interventionists were included, e.g., a sexologist. See Appendix A for the classifications of selfmanagement domains per study.

\subsection{Self-management interventions for different age groups}

Most interventions targeted 12 to 18 -year-olds $(n=36 ; 44.4 \%)$ or 7 to 11 -year-olds $(n=23 ; 28.4 \%)$. Only five SMI $(6.2 \%)$ targeted over 18 -year-olds. For the rest, age groups overlapped. Formats and classification of self-management domains did not seem to be related to specific age groups, but content or themes obviously were not applicable to the whole age range. For example, an intervention classified as targeting both role and emotion management for children (mean age 10 years) targeted communication and social problem solving in general [50], while for young people (mean age 20 years) such an intervention targeted the social subtheme of intimate relationships [64]. Another theme specific for older age groups is vocational participation. Two interventions aimed at the whole age range ( 7 to 25 years) addressed medical management and self-monitoring through daily diaries, respectively.

\subsection{Conceptualization of self-management: Theoretical bases of self- management interventions}

Fifty-five studies $(67.9 \%)$ either failed to state whether the interventions were based on a theory $(n=48)$ or, if they did so, did not specify the theoretical base $(n=7)$. Of the other studies, most referred to learning theories like Bandura's (cognitive) social learning theory or cognitive behavioral theory (Table 4). A theoretical base was mostly mentioned in relation to interventions targeting medical management alone, while only one of the studies evaluating role management interventions mentioned a theoretical base. In general, neither the content of interventions nor intervention characteristics were specific for a certain theoretical base.

\section{[TABLE 4]}

\subsection{Evaluating self-management interventions: Measured outcomes}

Interventions were evaluated on a wide variety of outcomes, primarily health outcomes (61.5\%), health-related quality of life (HRQoL) $(35.9 \%)$, and knowledge about the disease and/or treatment $(29.5 \%)$ (Table 5). 
Sattoe, J.N.T., Bal, M.I., Roelofs, P.D.D.M., Bal, R., Miedema, H.S., Staa, A. van. Self-management interventions for young people with chronic conditions: a systematic overview. Patient

\section{[TABLE 5]}

Interventions solely aimed at medical management $(n=36)$ were evaluated on all outcome measures except psychosocial functioning, and support by others. Of the five interventions solely aimed at role management, two were evaluated only on health outcomes, two on psychosocial functioning and one on social participation. One of the two emotion management intervention studies evaluated knowledge of disease and/or treatment, and the other social participation (Table 5). None of the outcomes or groups of outcomes could be related to one particular type of intervention and the distribution over self-management domains or combinations of self-management domains was quite unpredictable. Appendix A presents an overview of outcome measures per study (Table A.1) and the groups of outcomes (Table A.2).

\subsection{Linking content and outcomes: A content-based evaluation framework}

Regarding the content of interventions (Table 2), certain content logically relates to groups of outcomes or themes. If, for example, 'understanding of the disease' and 'adherence' is addressed, it would seem logical to evaluate intervention effectiveness from improved knowledge, clinical outcomes and self-reported adherence rather than from psychological outcomes such as depressive symptoms or anxiety. Grounded on this premise, a conceptual content-based measurement framework for the selection of outcome measures in the evaluation of SMI is presented in Fig. 3. The outcome measures correspond to the numbered content descriptions in Table 3. The only outcome related to all three domains was HRQoL.

\section{[FIGURE 3]}

\section{DISCUSSION AND CONCLUSION}

\subsection{Discussion}

\subsubsection{The focus of today's self-management support}

This review revealed that most interventions for young people represented in the literature solely aim at medical management, like interventions for adults $[17,113,114]$. This is not surprising, because medical tasks form the very core of healthcare. Moreover, these tasks represent common ground for healthcare professionals and people with chronic conditions, since medical consultations without fail will address symptoms and treatments. This may also explain why very few interventions address role management or emotion management alone. Still, the fact that $44 \%$ of interventions aim at multiple domains indicates a shift in focus of today's self-management support for young people with chronic conditions. Healthcare professionals nevertheless are challenged to pay more attention to role management and emotion management.

Six self-management skills match the tasks of medical, role and emotion management: "problem solving, decision making, resource utilization, the formation of a patient-provider partnership, action planning, and self-tailoring" [14]. Several SMI indeed were directed at developing such skills, e.g., drawing up an action plan. SMI content also seems to match self-management needs of people with chronic conditions, addressing the following processes: 'focusing on illness needs', 'activating resources', and 'living with a chronic illness' [21]. The first is addressed 
Sattoe, J.N.T., Bal, M.I., Roelofs, P.D.D.M., Bal, R., Miedema, H.S., Staa, A. van. Self-management interventions for young people with chronic conditions: a systematic overview. Patient Education and Counseling: 2015, 98(6), 704-715

in, for example, SMI aiming to deal with symptoms, the second in SMI helping young people realize when and how to ask support.

However, the above-mentioned processes basically reflect experiences of adult patients. Additional developmental processes or factors will relate to young people's self-management processes as well [115], such as 'determining health needs' and 'communication with the medical team', processes that have been incorporated in the Pediatric Self-management Model [15]. Several SMI indeed target such processes, albeit the Pediatric Self-management Model seems to more narrowly focus on medical management. Young people have to learn to balance or "articulate" [116] self-management tasks, which their parents use to be responsible for. Parental involvement can either hinder or facilitate adolescents' development of selfmanagement [117], and professionals and researchers should be aware of this $[15,117]$. Some SMI involved parents in the intervention or assessed family interaction or conflict. However, the notion that social context deserves attention when researching self-management, has only recently gained more attention $[14,17,19,117-120]$.

\subsubsection{The conceptualization of self-management support}

For most of the interventions a theoretical base was not provided, which was also found in other reviews of SMI for both adults and young people [16-18]. The studies that did mention a theoretical base often referred to social learning and cognitive behavioral theories which were also found to underlie SMI for adults [16,17]. Social learning theory argues that people learn from others and in general aims at enhancing self-efficacy [121], while employing an "experiential" approach to self-management [17]. In this view, self-management refers to learning about and believing in yourself, and self-management support facilitates environments that allow to 'learn from others' and gain 'mastery experiences'. On the other hand, cognitive behavioral theory aims to change thoughts and attitudes and ultimately behavior [122], and from this point of view self-management support might be targeted at behavior thought to be beneficial from a medical perspective. In this light, it could represent a more "authoritative" approach to self-management [17]. The different theoretical bases thus represent different views on self-management. For young people, the experiential approach seems more appealing, as telling them what to do is less effective. Young people tend to weigh medical advantages against social disadvantages [4]. Moreover, self-assurance would form a firm basis for healthy behavior [115].

\subsubsection{Evaluating self-management interventions: Losing focus on what we wish to achieve}

Outcome measures or themes varied greatly between studies and even within SMI aiming at a specific diagnostic group, as also reported by others [19]. Health outcomes predominated, which is not surprising given the focus on medical management. Remarkably, however, some studies that focused on a (partially) medical management intervention did not measure health outcomes. Likewise, some medical management interventions were evaluated with psychological outcomes, and an emotion management intervention was evaluated on knowledge of the disease. It seems that current evaluation studies tend to lose focus on what interventions are aimed at, which also hampers conclusions about their effectiveness. Others have 
Sattoe, J.N.T., Bal, M.I., Roelofs, P.D.D.M., Bal, R., Miedema, H.S., Staa, A. van. Self-management interventions for young people with chronic conditions: a systematic overview. Patient Education and Counseling: 2015, 98(6), 704-715

recognized this, too, and recommend use of a core set of measurement outcomes to evaluate SMI $[19,22,123]$.

\subsubsection{A content-based framework for the selection of outcome measures or groups of outcome measures}

The framework presented in Fig. 3 proposes a start for a more standardized evaluation approach for SMI for young people with chronic conditions. The outcomes matched those in comparable reviews $[18,19]$, which strengthens the validity of the framework. It may be used to select outcome measures on the basis of the specific content of interventions (as described and numbered per domain in Table 3 ). However, the classification is broad and measures must be selected based on the goal of the intervention and the measurement properties of the measure. Further sharpening requires more studies into outcomes and measurement instruments. A fact worth mentioning is the lack of qualitative evaluation studies for SMI. Since qualitative research delves into the contexts of interventions, we recommend future studies to employ a mixed-methods design including a qualitative component. This would help identify 'effective ingredients' of SMI and answer the question of what works for whom [124]. The outcome measures in our framework may serve as themes for qualitative research, but themes related to the characteristics of interventions need to be included as well.

\subsubsection{Strengths, limitations and other considerations}

This study included a systematic and comprehensive search, and was the first to review content of pediatric SMI and classify interventions using a broad selfmanagement framework. Other recent reviews in this field that focus particularly on children and/or adolescents (0-18 years), aimed at researching the effectiveness of SMI and included only RCT's or studies with repeated measures designs [18,19]. In contrast, our study shed light on the broad content and range of today's selfmanagement support for young people with chronic conditions. As such, we dealt with the more fundamental question of what exactly is meant by self-management and self-management support. Furthermore, by matching content of SMI and outcome measures used, a selection tool for future evaluation studies was presented. This also corresponds to the fundamental question of what might be expected from self-management support, and provides a first step towards a much-needed general evaluation framework for different types of interventions.

Lorig \& Holman's model is often referred to in the self-management literature and seems valid to classify SMI in children, adolescents and young adults, because our results showed that SMI aimed at certain domains of self-management are not exclusive for age groups. This does not imply that certain content is applicable to all ages; for example, vocational participation is more relevant for older adolescents than for younger children. Differences between age groups should therefore be taken into account when evaluating SMI.

This study looked at many types of SMI across a range of chronic conditions. This may be a limitation, because our search terms did not include specific chronic conditions and we might have missed studies that did not include specific key words from our search. However, we feel this is always an issue when performing a systematic literature review which probably is more related to the way databases are organized than to the sensitivity of our search strategy. Furthermore, our non- 
Sattoe, J.N.T., Bal, M.I., Roelofs, P.D.D.M., Bal, R., Miedema, H.S., Staa, A. van. Self-management interventions for young people with chronic conditions: a systematic overview. Patient Education and Counseling: 2015, 98(6), 704-715

categorical approach may also be a strength, because it enables a more general view on self-management irrespective of diagnosis. This is relevant because these young people face comparable challenges and similar adaptive tasks irrespective of type of condition $[4,115]$. Yet, they may need different support in view of individual sociodemographic and psychological factors [117]. In this respect young people within a specific diagnostic group may differ as much as those in different diagnostic groups [125]. Interestingly, only 7\% of the SMI found in the present study were developed for chronic conditions in general. Since specific pediatric diagnostic groups are often small, achieving effectiveness and cost-effectiveness of disease-specific SMI would be problematic [20]. A more generic approach with a disease-specific component for different diagnostic groups may be more convenient [4], and should not be problematic since the core elements of self-management support are the same across different approaches [126]. An example is the 'Skills for Growing Up' tool developed in pediatric rehabilitation and adjusted on disease-specific content for use in pediatric nephrology [127].

Gaining insight into effectiveness of different types of interventions was hindered by the heterogeneity in outcome measures. Most studies in this review were from Western countries, and interventions for young people with diabetes or asthma predominated. These conditions generally include a burdensome medical regimen, which may have added to the focus on medical management. Yet, a sub-analysis (not presented in this paper) showed that even after removing diabetes and asthma studies, the focus still remained on medical management alone than on other selfmanagement domains.

\subsection{Conclusions}

The content of different SMI relate to self-management tasks of people with chronic conditions, and self-management skills they should develop. Yet, healthcare professionals should be aware of the importance of role and emotion management in self-management. Also, in view of these young people's developmental challenges, an experiential approach focusing on learning (from others) and 'mastery experiences' might be more appropriate in pediatric care.

Future evaluations should provide details about theoretical bases of interventions, and should match evaluation outcomes and themes to intervention content and characteristics. The content-based evaluation framework presented in this study may assist in this, while further research might help identify valid outcome measurement instruments. Mixed-methods research is recommended to gain more insights in the contexts, including social context, and working mechanisms of SMI.

\subsection{Practice implications}

Self-management support is important for people with chronic conditions to help them deal with their condition in daily life. This is even more pertinent to young people growing up with chronic conditions, who have to face the normal tasks of development (e.g., acquiring autonomy) and have to engage in lifelong medical management of their condition. Therefore, it remains important to research the effects of SMI. Future evaluation studies should make sure that their evaluation outcomes match with the content and characteristics of the SMI, and may benefit from the use of more generic outcome measures in SMI evaluation. Our contentbased evaluation framework and overview of SMI content, characteristics and outcomes may assist researchers in doing so. Furthermore, our overview may give 
Sattoe, J.N.T., Bal, M.I., Roelofs, P.D.D.M., Bal, R., Miedema, H.S., Staa, A. van. Self-management interventions for young people with chronic conditions: a systematic overview. Patient Education and Counseling: 2015, 98(6), 704-715

clinicians and other healthcare professionals insight into the broad range of selfmanagement and self-management support, and as such may assist them in determining the breadth and focus of the support they provide.

\section{ACKNOWLEDGEMENTS}

The study was part of the Self-management and Participation Innovation Lab, supported by SIA-RAAK, the Foundation Innovation Alliance with funding from the Dutch Ministry of Education, Culture and Science (OCW) (PRO-02-025). The authors thank the information specialist of the Erasmus MC medical library, Wichor Bramer, for his assistance in defining the search strategy. Ko Hagoort is thanked for his editorial assistance. Finally, the members of our Self-management \& Participation Research Group (Rotterdam University of Applied Sciences) and Hester van de Bovenkamp (Erasmus University Rotterdam) are thanked for their comments on an earlier draft of this paper.

\section{APPENDIX A. SUPPLEMENTARY DATA}

The following are the supplementary data to this article:

\section{REFERENCES}

[1] The Child and Adolescent Health Measurement Initiative. National survey of children with special health care needs. The Child and Adolescent Health Measurement Initiative (2012) <http://www.childhealthdata.org/learn/NS-CSHCN> (accessed: 11 April 2014)

[2] L.B. Mokkink, J.H. van der Lee, M.A. Grootenhuis, M. Offringa, B.M.S. van Praag, H.S.A. Heymans. mvang en gevolgen van chronische aandoeningen bij kinderen [Extent and consequences of chronic conditions in children] Tijdschrift voor Kindergeneeskunde [Dutch J Pediatr], 75 (2007), pp. 138-142

[3] R. Gijsen, S.H. van Oostrom, F.C. Schellevis. Hoeveel mensen hebben één of meer chronische ziekten? [How many people have on or more chronic diseases?] Volksgezondheid Toekomst Verkenning, Nationaal Kompas Volksgezondheid, RIVM, Bilthoven (2013)

[4] A.L. Van Staa. On your own feet: adolescents with chronic conditions and their preferences and competencies for care. Rotterdam University, Rotterdam (2012) (Doctoral dissertation)

[5] Y. Ratanachadawan, A. response to, T. Koch, P. Jenkin, D. Kralik. hronic illness selfmanagement: locating the 'self'. J Adv Nurs, 52 (2004), pp. 571-572 2005

[6] P.W. Harvey, J.N. Petkov, G. Misan, J. Fuller, M.W. Battersby, T.N. Cayetano, et al. Selfmanagement support and training for patients with chronic and complex conditions improves health-related behaviour and health outcomes. Aust Health Rev, 32 (2008), pp. 330-338

[7] E.H. Wagner. Chronic disease management: what will it take to improve care for chronic illness? Eff Clin Pract, 1 (1998), pp. 2-4

[8] J. Trappenburg, N. Jonkman, T. Jaarsma, H. van Os-Medendorp, H. Kort, N. de Wit, et al. Self-management: one size does not fit all. Patient Educ Couns, 92 (2013), pp. 134-137 ArticlePDF (202KB)

[9] M. Huber, J.A. Knottnerus, L. Green, H. van der Horst, A.R. Jadad, D. Kromhout, et al. How should we define health? Brit Med J, 343 (2011), p. d4163

[10] Å. Audulv, K.-G. Norbergh, K. Asplund, A. Hörnsten. An ongoing process of inner negotiation-a grounded theory study of self-management among people living with chronic illness. J Nurs Healthc Chronic Illn, 1 (2009), pp. 283-293

[11] B.L. Paterson. The shifting perspectives model of chronic illness. J Nurs Scholarsh, 33 (2001), pp. 21-26 
Sattoe, J.N.T., Bal, M.I., Roelofs, P.D.D.M., Bal, R., Miedema, H.S., Staa, A. van. Self-management interventions for young people with chronic conditions: a systematic overview. Patient Education and Counseling: 2015, 98(6), 704-715

[12] J. Barlow, C. Wright, J. Sheasby, A. Turner, J. Hainsworth. Self-management approaches for people with chronic conditions: a review. Patient Educ Couns, 48 (2002), pp. 177-187

[13] A.A. Richard, K. Shea. Delineation of self-care and associated concepts. J Nurs Scholarsh, 43 (2011), pp. 255-264

[14] K.R. Lorig, H. Holman. Self-management education: history, definition, outcomes, and mechanisms. Ann Behav Med, 26 (2003), pp. 1-7

[15] A.C. Modi, A.L. Pai, K.A. Hommel, K.K. Hood, S. Cortina, M.E. Hilliard, et al. Pediatric self-management: a framework for research, practice, and policy. Pediatric, 129 (2012), pp. e473-e485

[16] S. Newman, L. Steed, K. Mulligan. Chronic physical illness: self-management and behavioural interventions. Open University Press, New York, NY (2009)

[17] H. Jonsdottir. Self-management programmes for people living with chronic obstructive pulmonary disease: a call for a reconceptualisation. J Clin Nurs, 22 (2013), pp. 621-637

[18] S. Kirk, S. Beatty, P. Callery, J. Gellatly, L. Milnes, S. Pryjmachuk. The effectiveness of self-care support interventions for children and young people with long-term conditions: a systematic review. Child Care Health Dev, 39 (2012), pp. 305-324

[19] S. Lindsay, S. Kingsnorth, C. McDougall, H. Keating. A systematic review of selfmanagement interventions for children and youth with physical disabilities

Disabil Rehabil, 36 (2014), pp. 276-288

[20] S. Newman, K. Mulligan, L. Steed. What is meant by self-management and how can its efficacy be established? Rheumatology, 40 (2001), pp. 1-4

[21] D. Schulman-Green, S. Jaser, F. Martin, A. Alonzo, M. Grey, R. McCorkle, et al. Processes of self-management in chronic illness. J Nurs Scholarsh, 44 (2012), pp. 136-144

[22] S. Nolte, G.R. Elsworth, S. Newman, R.H. Osborne. Measurement issues in the evaluation of chronic disease self-management programs. Qual Life Res, 22 (2013), pp. 1655-1664

[23] M.J. Grant, A. Booth. A typology of reviews: an analysis of 14 review types and associated methodologies. Health Info Libr J, 26 (2009), pp. 91-108

[24] D. Moher, A. Liberati, J. Tetzlaff, D.G. Altman, PRISMA Group. Preferred reporting items for systematic reviews and meta-analyses: the PRISMA statement. PLoS Med, 6 (2009), p. e1000097

[25] Scottish Intercollegiate Guidelines Network. Critical appraisal: notes and checklists. Scottish Intercollegiate Guidelines Network (2013) <http://www.sign.ac.uk/methodology/checklists.html\#> (accessed: 17 June 2013)

[26] A. Tong, P. Sainsbury, J. Craig. Consolidated criteria for reporting qualitative research (COREQ): a 32-item checklist for interviews and focus groups. Int J Qual Health Care, 19 (2007), pp. 349-357

[27] H. Rhee, M.J. Belyea, J.F. Hunt, J. Brasch. Effects of a peer-led asthma selfmanagement program for adolescents. Arch Pediatr Adolesc Med, 165 (2011), pp. 513-519

[28] H. Rhee, B.E. McQuillan, M.J. Belyea. Evaluation of a peer-led asthma selfmanagement program and benefits of the program for adolescent peer leaders. Respir Care, 57 (2012), pp. 2082-2089

[29] S.M. Ng, A.M. Li, V.W. Lou, I.F. Tso, P.Y. Wan, D.F. Chan. Incorporating family therapy into asthma group intervention: a randomized waitlist-controlled trial. Fam process, 47 (2008), pp. 115-130

[30] R.L. Jan, J.Y. Wang, M.C. Huang, S.M. Tseng, H.J. Su, L.F. Liu. An internet-based interactive telemonitoring system for improving childhood asthma outcomes in Taiwan. Telemed J E Health, 13 (2007), pp. 257-268

[31] P.V. Burkhart, M.K. Rayens, M.G. Oakley, D.A. Abshire, M. Zhang. Testing an intervention to promote children's adherence to asthma self-management. J Nurs Scholarsh, 39 (2007), pp. 133-140

[32] A. Butz, L. Pham, L. Lewis, C. Lewis, K. Hill, J. Walker, et al. Rural children with asthma: impact of a parent and child asthma education program. J Asthma, 42 (2005), pp. 813-821

[33] N.M. Clark, S. Shah, J.A. Dodge, L.J. Thomas, R.R. Andridge, R.J.A. Little. An evaluation of asthma interventions for preteen students. J Sch Health, 80 (2010), pp. 80-87 
Sattoe, J.N.T., Bal, M.I., Roelofs, P.D.D.M., Bal, R., Miedema, H.S., Staa, A. van. Self-management interventions for young people with chronic conditions: a systematic overview. Patient

Education and Counseling: 2015, 98(6), 704-715

[34] K. Huss, M. Winkelstein, J. Nanda, P.L. Naumann, E.D. Sloand, R.W. Huss. Computer game for inner-city children does not improve asthma outcomes. J Pediatr Health Care, 17 (2003), pp. 72-78

[35] C.L. Joseph, E. Peterson, S. Havstad, C.C. Johnson, S. Hoerauf, S. Stringer, et al. A web-based, tailored asthma management program for urban African-American high school students. Am J Respir Crit Care Med, 175 (2007), pp. 888-895

[36] S. Krishna, B.D. Francisco, E.A. Balas, P. Konig, G.R. Graff, R.W. Madsen, et al. Internet-enabled interactive multimedia asthma education program: a randomized trial. Pediatrics, 111 (2003), pp. 503-510

[37] E.R. Pulgaron, K.S. Salamon, C.A. Patterson, L.P. Barakat. A problem-solving intervention for children with persistent asthma: a pilot of a randomized trial at a pediatric summer camp. J Asthma, 47 (2010), pp. 1031-1039

[38] R.S. Shames, P. Sharek, M. Mayer, T.N. Robinson, E.G. Hoyte, F. Gonzalez-Hensley, et al. Effectiveness of a multicomponent self-management program in at-risk, school-aged children with asthma. Ann Allergy Asthma Immunol, 92 (2004), pp. 611-618

[39] B. Velsor-Friedrich, T. Pigott, B. Srof. A practitioner-based asthma intervention program with African American inner-city school children. J Pediatr Health Care, 19 (2005), pp. 163171

[40] P. Hampel, H. Rudolph, R. Stachow, F. Petermann. Multimodal patient education program with stress management for childhood and adolescent asthma. Patient Educ Couns, 49 (2003), pp. 59-66

[41] L.C. Chiang, W.F. Ma, J.L. Huang, L.F. Tseng, K.C. Hsueh. Effect of relaxationbreathing training on anxiety and asthma signs/symptoms of children with moderate-tosevere asthma: a randomized controlled trial. Int J Nurs Stud, 46 (2009), pp. 1061-1070

[42] A. Beebe, E.W. Gelfand, B. Bender. A randomized trial to test the effectiveness of art therapy for children with asthma. J Allergy Clin Immunol, 126 (2010), pp. 263-266

[43] N.M. Clark, R. Brown, C.L. Joseph, E.W. Anderson, M. Liu, M.A. Valerio. Effects of a comprehensive school-based asthma program on symptoms, parent management, grades, and absenteeism. Chest, 125 (2004), pp. 1674-1679

[44] J. Kouba, B. Velsor-Friedrich, L. Militello, P.R. Harrison, A. Becklenberg, B. White, et al. Efficacy of the i can control asthma and nutrition now (ICAN) pilot program on health outcomes in high school students with asthma. J School Nurs, 29 (2013), pp. 235-247

[45] B. Rami, C. Popow, W. Horn, T. Waldhoer, E. Schober. Telemedical support to improve glycemic control in adolescents with type 1 diabetes mellitus. Eur J Pediatr, 165 (2006), pp. 701-705

[46] J.A. Cafazzo, M. Casselman, N. Hamming, D.K. Katzman, M.R. Palmert. Design of an mHealth App for the self-management of adolescent Type 1 diabetes: a pilot study. J Med Internet Res, 14 (2012), pp. 171-183

[47] R.N. Løding, J.E. Wold, A. Skavhaug. Experiences with a group intervention for adolescents with type 1 diabetes and their parents. Eur Diab Nursing, 5 (2008), pp. 9-14

[48] V.L. Franklin, A. Waller, C. Pagliari, S.A. Greene. A randomized controlled trial of sweet talk, a text-messaging system to support young people with diabetes Diabet Med, 23 (2006), pp. 1332-1338

[49] C. Martin, K. Liveley, K. Whitehead. A health education group intervention for children with type 1 diabetes. J Diabetes Nurs, 13 (2009), pp. 32-37

[50] B.S. Gerber, M.C. Solomon, T.L. Shaffer, M.T. Quinn, R.B. Lipton. Evaluation of an internet diabetes self-management training program for adolescents and young adults. Diabetes Technol Ther, 9 (2007), pp. 60-67

[51] M. Grey, R. Whittemore, S. Jaser, J. Ambrosino, E. Lindemann, L. Liberti, et al. Effects of coping skills training in school-age children with type 1 diabetes. Res Nurs Health, 32 (2009), pp. 405-418

[52] D.A. Hanauer, K. Wentzell, N. Laffel, L.M. Laffel. Computerized Automated Reminder Diabetes System (CARDS): e-mail and SMS cell phone text messaging reminders to support diabetes management. Diabetes Technol Ther, 11 (2009), pp. 99-106

[53] V.S. Kumar, K.J. Wentzell, T. Mikkelsen, A. Pentland, L.M. Laffel. The DAILY (Daily Automated Intensive Log for Youth) trial: a wireless, portable system to improve adherence and glycemic control in youth with diabetes. Diabetes Technol Ther, 6 (2004), pp. 445-453 
Sattoe, J.N.T., Bal, M.I., Roelofs, P.D.D.M., Bal, R., Miedema, H.S., Staa, A. van. Self-management interventions for young people with chronic conditions: a systematic overview. Patient Education and Counseling: 2015, 98(6), 704-715

[54] L.M. Laffel, L. Vangsness, A. Connell, A. Goebel-Fabbri, D. Butler, B.J. Anderson. Impact of ambulatory, family-focused teamwork intervention on glycemic control in youth with type 1 diabetes. J Pediatr, 142 (2003), pp. 409-416

[55] T.R. Nansel, R.J. lannotti, B.G. Simons-Morton, C. Cox, L.P. Plotnick, L.M. Clark, et al. Diabetes personal trainer outcomes: short-term and 1-year outcomes of a diabetes personal trainer intervention among youth with type 1 diabetes. Diabetes Care, 30 (2007), pp. 2471-2477

[56] Y.C. Wang, S. Stewart, E. Tuli, P. White. Improved glycemic control in adolescents with type 1 diabetes mellitus who attend diabetes camp. Pediatr Diabetes, 9 (2008), pp. 29-34

[57] T. Wysocki, M.A. Harris, L.M. Buckloh, D. Mertlich, A.S. Lochrie, N. Mauras, et al. Randomized trial of behavioral family systems therapy for diabetes: maintenance of effects on diabetes outcomes in adolescents. Diabetes Care, 30 (2007), pp. 555-560

[58] S.J. Channon, M.V. Huws-Thomas, S. Rollnick, K. Hood, R.L. Cannings-John, C. Rogers, et al. A multicenter randomized controlled trial of motivational interviewing in teenagers with diabetes. Diabetes Care, 30 (2007), pp. 1390-1395

[59] K.T. Newton, A. Ashley. Pilot study of a web-based intervention for adolescents with type 1 diabetes. J Telemed Telecare, 19 (2013), pp. 443-449

[60] L.J. Herbert, R. Sweenie, K.P. Kelly, C. Holmes, R. Streisand. Using qualitative methods to evaluate a family behavioral intervention for type 1 diabetes. J Pediatr Health Care, 28 (2014), pp. 376-385

[61] M. Barrera, F. Schulte. A group social skills intervention program for survivors of childhood brain tumors. J Pediatr Psychol, 34 (2009), pp. 1108-1118

[62] A.L. Canada, L.R. Schover, Y. Li. A pilot intervention to enhance psychosexual development in adolescents and young adults with cancer. Pediatr Blood Cancer, 49 (2007), pp. 824-828

[63] J.K. Jones, S.A. Kamani, P.J. Bush, K.A. Hennessy, A. Marfatia, A.T. Shad.

Development and evaluation of an educational interactive CD-ROM for teens with cancer. Pediatr Blood Cancer, 55 (2010), pp. 512-519

[64] H. Maurice-Stam, L.M. Silberbusch, B.F. Last, M.A. Grootenhuis. Evaluation of a psycho-educational group intervention for children treated for cancer: a descriptive pilot study. Psychooncology, 18 (2009), pp. 762-766

[65] P.M. Kato, S.W. Cole, A.S. Bradlyn, B.H. Pollock. A video game improves behavioral outcomes in adolescents and young adults with cancer: a randomized trial. Pediatrics, 122 (2008), pp. e305-e317

[66] M. Stulemeijer, L.W.A.M. De Jong, T.J.W. Fiselier, S.W.B. Hoogveld, G. Bleijenberg. Cognitive behaviour therapy for adolescents with chronic fatigue syndrome: randomised controlled trial. Br Med J, 330 (2005), pp. 14-17

[67] S.R. Hilberink, E. Kruijver, D.J.H.G. Wiegerink, T.P.M. Vliet Vlieland. A pilot implementation of an intervention to promote sexual health in adolescents and young adults in rehabilitation. Sex Disabil, 31 (2013), pp. 1-20

[68] S. Torok, G. Kokonyei, L. Karolyi, A. Ittzes, T. Tomcsanyi. Outcome effectiveness of therapeutic recreation camping program for adolescents living with cancer and diabetes. $J$ Adolesc Health, 39 (2006), pp. 445-447

[69] A. Bekesi, S. Torok, G. Kokonyei, I. Bokretas, A. Szentes, G. Telepoczki. Health-related quality of life changes of children and adolescents with chronic disease after participation in therapeutic recreation camping program. Health Qual Life Outcomes, 9 (2011), p. 43

[70] C. Curle, J. Bradford, J. Thompson, P. Cawthron. Users' views of a group therapy intervention for chronically ill or disabled children and their parents: towards a meaningful assessment of therapeutic effectiveness. Clin Child Psychol Psychiatry, 10 (2005), pp. 509527

[71] D. Creedy, D. Collis, T. Ludlow, S. Cosgrove, K. Houston, D. Irvine, et al. Development and evaluation of an intensive intervention program for children with a chronic health condition: a pilot study. Contemp Nurse, 18 (2004), pp. 46-56

[72] P. Raghavendra, L. Newman, E. Grace, Wood D.: 'I could never do that before': effectiveness of a tailored internet support intervention to increase the social participation of youth with disabilities. Child Care Health Dev, 39 (2013), pp. 552-561 
Sattoe, J.N.T., Bal, M.I., Roelofs, P.D.D.M., Bal, R., Miedema, H.S., Staa, A. van. Self-management interventions for young people with chronic conditions: a systematic overview. Patient Education and Counseling: 2015, 98(6), 704-715

[73] T. Hechler, M. Dobe, U. Damschen, M. Blankenburg, S. Schroeder, J. Kosfelder, et al. The pain provocation technique for adolescents with chronic pain: preliminary evidence for its effectiveness. Pain Med (USA), 11 (2010), pp. 897-910

[74] C. Eccleston, P.N. Malleson, J. Clinch, H. Connell, C. Sourbut. Chronic pain in adolescents: evaluation of a programme of interdisciplinary cognitive behaviour therapy. Arch Dis Child, 88 (2003), pp. 881-885

[75] T.M. Palermo, A.C. Wilson, M. Peters, A. Lewandowski, H. Somhegyi. Randomized controlled trial of an Internet-delivered family cognitive-behavioral therapy intervention for children and adolescents with chronic pain. Pain, 146 (2009), pp. 205-213

[76] V.P.B.M. Merlijn, J.A.M. Hunfeld, J.C. van der Wouden, A.A.J.M. HazebroekKampschreur, L.W.A. van Suijlekom-Smit, B.W. Koes, et al. A cognitive-behavioural program for adolescents with chronic pain-a pilot study. Patient Educ Couns, 59 (2005), pp. 126-134

[77] J. Fales, T.M. Palermo, E.F. Law, A.C. Wilson. Sleep outcomes in youth with chronic pain participating in a randomized controlled trial of online cognitive-behavioral therapy for pain management. Behav Sleep Med, 13 (2) (2015), pp. 107-123

[78] P.A. Newcombe, T.L. Dunn, L.M. Casey, J.K. Sheffield, H. Petsky, S. Anderson-James, et al. Breathe easier online: evaluation of a randomized controlled pilot trial of an Internetbased intervention to improve well-being in children and adolescents with a chronic respiratory condition. J Med Internet Res, 14 (2012), pp. 115-126

[79] J.A. Downs, C.M. Roberts, A.M. Blackmore, P.N. Le Souef, S.C. Jenkins. Benefits of an education programme on the self-management of aerosol and airway clearance treatments for children with cystic fibrosis. Chronic Respir Dis, 3 (2006), pp. 19-27

[80] K. MacDonald, A. Greggans. 'Cool friends': an evaluation of a community befriending programme for young people with cystic fibrosis. J Clin Nurs, 19 (2010), pp. 2406-2414

[81] B.J. Christian, J.P. D’Auria. Building life skills for children with cystic fibrosis: effectiveness of an intervention. Nurs Res, 55 (2006), pp. 300-307

[82] M.A. Davis, A.L. Quittner, C.M. Stack, M.C.K. Yang. Controlled evaluation of the STARBRIGHT CD-ROM program for children and adolescents with cystic fibrosis. J Pediatr Psychol, 29 (2004), pp. 259-267

[83] D. Staab, T.L. Diepgen, M. Fartasch, J. Kupfer, T. Lob-Corzilius, J. Ring, et al. Age related structured educational programmes for the management of atopic dermatitis in children adolescents: multicentre randomised controlled trial. Brit Med J, 332 (2006), pp. 933-938

[84] M.A. Meade, T.L. Creer, J.D. Mahan. A self-management program for adolescents and children with renal transplantation. J Clin Psychol Med Settings, 10 (2003), pp. 165-171

[85] M.E. Payne, C.K. Eaton, L.L. Mee, R.L. Blount. Promoting medication adherence and regimen responsibility in two adolescents on hemodialysis for end-stage renal disease: a case study. Clin Case Stud, 12 (2013), pp. 95-110

[86] J.N.T. Sattoe, S. Jedeloo, A. Van Staa. Effective peer-to-peer support for young people with end-stage renal disease: a mixed methods evaluation of Camp COOL. BMC Nephrol, 14 (2013), p. 279

[87] S. Cushner-Weinstein, M. Berl, J.A. Salpekar, J.L. Johnson, P.L. Pearl, J.A. Conry, et al. The benefits of a camp designed for children with epilepsy: evaluating adaptive behaviors over 3 years. Epilepsy Behav, 10 (2007), pp. 170-178

[88] M.W. Bultas, C. Budhathoki, K. Balakas. Evaluation of child and parent outcomes after a pediatric cardiac camp experience. J Spec Pediatr Nurs, 18 (2013), pp. 320-328

[89] M.C. Smith Fawzi, E. Eustache, C. Oswald, E. Louis, P.J. Surkan, F. Scanlan, et al. Psychosocial support intervention for HIV-affected families in Haiti: Implications for programs and policies for orphans and vulnerable children. Soc Sci Med, 74 (2012), pp. 1494-1503

[90] V.M. Berrien, J.C. Salazar, E. Reynolds, K. McKay, HIVMAI Group. Adherence to antiretroviral therapy in HIV-infected pediatric patients improves with home-based intensive nursing intervention. AIDS Patient Care STDs, 18 (2004), pp. 355-363

[91] L.G. Hayutin, R.L. Blount, J.D. Lewis, L.E. Simons, M.L. McCormick Skills-based group intervention for adolescent girls with inflammatory bowel disease. Clin Case Stud, 8 (2009), pp. $355-365$ 
Sattoe, J.N.T., Bal, M.I., Roelofs, P.D.D.M., Bal, R., Miedema, H.S., Staa, A. van. Self-management interventions for young people with chronic conditions: a systematic overview. Patient

Education and Counseling: 2015, 98(6), 704-715

[92] H. Dufresne, S. Hadj-Rabia, C. Taieb, C. Bodemer. Importance of therapeutic patient education in ichthyosis: results of a prospective single reference center study. Orphanet $J$ Rare Dis, 8 (2013), p. 113

[93] S. Kashikar-Zuck, T.V. Ting, L.M. Arnold, J. Bean, S.W. Powers, T.B. Graham, et al. Cognitive behavioral therapy for the treatment of juvenile fibromyalgia: a multisite, singleblind, randomized, controlled clinical trial. Arthritis Rheum, 64 (2012), pp. 297-305

[94] S. Kashikar-Zuck, S.R. Flowers, D. Strotman, S. Sil, T.V. Ting, K.N. Schikler. Physical activity monitoring in adolescents with juvenile fibromyalgia: findings from a clinical trial of cognitive-behavioral therapy. Arthritis Care Res (Hoboken), 65 (2013), pp. 398-405

[95] S. Kashikar-Zuck, S. Sil, A.M. Lynch-Jordan, T.V. Ting, J. Peugh, K.N. Schikler, et al. Changes in pain coping, catastrophizing, and coping efficacy after cognitive-behavioral therapy in children and adolescents with juvenile fibromyalgia. J Pain, 14 (2013), pp. 492501

[96] J.N. Stinson, P.J. McGrath, E.D. Hodnett, B.M. Feldman, C.M. Duffy, A.M. Huber, et al .An internet-based self-management program with telephone support for adolescents with arthritis: a pilot randomized controlled trial. J Rheumatol, 37 (2010), pp. 1944-1952

[97] J. Hackett, B. Johnson, K.L. Shaw, J.E. McDonagh. Friends united: an evaluation of an innovative residential self-management programme in adolescent rheumatology. $\mathrm{Br} \mathrm{J}$ Occup Ther, 68 (2005), pp. 567-573

[98] J.E. McDonagh, T.R. Southwood, K.L. Shaw. The impact of a coordinated transitional care programme on adolescents with juvenile idiopathic arthritis. Rheumatology (UK), 46 (2007), pp. 161-168

[99] C.E. Fuchs, S.M. Van Geelen, H.J.M. Hermans, E.M. Van De Putte, R. Van Geel, G. Sinnema, et al. Psychological intervention for adolescents with juvenile idiopathic arthritis: for whom and when? J Rheumatol, 40 (2013), pp. 528-534

[100] M. Connelly, M.A. Rapoff, N. Thompson, W. Connelly. Headstrong: a pilot study of a CD-ROM intervention for recurrent pediatric headache. J Pediatr Psychol, 31 (2006), pp. 737-747

[101] A.E. Ten Hoedt, C.E. Hollak, C.C. Boelen, N.A.P. van der Herberg-van de Wetering, N.M. Ter Horst, C.F. Jonkers, et al .MY PKU": increasing self-management in patients with phenylketonuria. A randomized controlled trial. Orphanet J Rare Dis, 6 (2011), p. 48

[102] A.L. Hojberg, B.F. Steffensen. Developing and maintaining of user-defined personal competencies among young adults with congenital physical disability. Dev Neurorehabil, 11 (2010), pp. 225-235

[103] N. Xenakis, J. Goldberg. The young women's program: a health and wellness model to empower adolescents with physical disabilities. Disabil Health J, 3 (2010), pp. 125-129

[104] J.A.C. Verhoef, M.E. Roebroeck, N. van Schaardenburgh, M.C.S.G. Floothuis, H.S. Miedema. Improved occupational performance of young adults with a physical disability after a vocational rehabilitation intervention. J Occup Rehabil, 24 (2014), pp. 42-51

[105] L.P. Barakat, L.A. Schwartz, K.S. Salamon, J. Radcliffe. A family-based randomized controlled trial of pain intervention for adolescents with sickle cell disease. J Pediatr Hematol Oncol, 32 (2010), pp. 540-547

[106] C.B. McClellan, J.C. Schatz, E. Puffer, C.E. Sanchez, M.T. Stancil, C.W. Roberts. Use of handheld wireless technology for a home-based sickle cell pain management protocol. $J$ Pediatr Psychol, 34 (2009), pp. 564-573

[107] K. Koontz, A.D. Short, K. Kalinyak, R.B. Noll. A randomized, controlled pilot trial of a school intervention for children with sickle cell anemia. J Pediatr Psychol, 29 (2004), pp. 7 17

[108] S.L. Yoon, A. Godwin. Enhancing self-management in children with sickle cell disease through playing a CD-ROM educational game: a pilot study. Pediatr Nurs, 33 (60-3) (2007), p. 72

[109] C.E. Dobson, M.W. Byrne. Using guided imagery to manage pain in young children with sickle cell disease. Am J Nurs, 114 (2014), pp. 26-36

[110] C.L. Betz, K. Smith, K. Macias. Testing the transition preparation training program: a randomized controlled trial. Int J Child Adolesc health, 3 (2011), pp. 595-607

[111] K. O'Mahar, G.N. Holmbeck, B. Jandasek, J. Zukerman. A camp-based intervention targeting independence among individuals with spina bifida. J Pediatr Psychol, 35 (2010), pp. 848-856 
Sattoe, J.N.T., Bal, M.I., Roelofs, P.D.D.M., Bal, R., Miedema, H.S., Staa, A. van. Self-management interventions for young people with chronic conditions: a systematic overview. Patient Education and Counseling: 2015, 98(6), 704-715

[112] C.E. Holbein, C.B. Murray, A.M. Psihogios, R.M. Wasserman, B.S. Essner, L.K. O'Hara, et al. A camp-based psychosocial intervention to promote independence and social function in individuals with spina bifida: moderators of treatment effectiveness. $J$ Pediatr Psychol, 38 (2013), pp. 412-424

[113] K.A. Udlis. Self-management in chronic illness: concept and dimensional analysis. J Nurs Healthc Chronic IIIn (2011), pp. 130-139

[114] T. Koch, P. Jenkin, D. Kralik. Chronic illness self-management: locating the 'self'. J Adv Nurs, 48 (2004), pp. 484-492

[115] S.M. Sawyer, S. Drew, M.S. Yeo, M.T. Britto. Adolescents with a chronic condition: challenges living, challenges treating. Lancet, 369 (2007), pp. 1481-1489

[116] J.M. Corbin, A.L. Strauss. Unending work and care: managing chronic illness at home. Jossey-Bass, San Francisco, CA (1988)

[117] S. Kirk, S. Beatty, P. Callery, L. Milnes, S. Pryjmachuk. Perceptions of effective selfcare support for children and young people with long-term conditions. J Clin Nurs, 21 (2012), pp. 1974-1987

[118] L.M. Thirsk, A.M. Clark. What is the 'self' in chronic disease self-management? Int J Nurs Stud, 51 (2014), pp. 691-693

[119] A. Audulv, K. Asplund, K.G. Norbergh. The integration of chronic illness selfmanagement. Qual Health Res, 22 (2012), pp. 332-345

[120] B.N. Ong, A. Rogers, A. Kennedy, P. Bower, T. Sanders, A. Morden, et al. Behaviour change and social blinkers? The role of sociology in trials of self-management behaviour in chronic conditions. Sociol Health IIIn, 36 (2014), pp. 226-238

[121] A. BanduraSocial learning theory. General Learning Press, New York, NY (1977)

[122] S.D.A. Hupp, D. Reitman, J.D. Jewell. Cognitive behavioral theory. John Wiley \& Sons, Inc, New York, NY (2008)

[123] S. Nolte, R.H. Osborne. A systematic review of outcomes of chronic disease selfmanagement interventions. Qual Life Res, 22 (2013), pp. 1805-1816

[124] S. Coster, I. Norman. Cochrane reviews of educational and self-management interventions to guide nursing practice: a review. Int J Nurs Stud, 46 (2009), pp. 508-528

[125] R.E. Stein, D.J. Jessop. What diagnosis does not tell: the case for a noncategorical approach to chronic illness in childhood. Soc Sci Med, 29 (1989), pp. 769-778

[126] M. Novak, L. Costantini, S. Schneider, H. Beanlands. Approaches to self-management in chronic illness. Semin Dial, 26 (2013), pp. 188-194

[127] J.N.T. Sattoe, S.R. Hilberink, M.A.C. Peeters, A. van Staa. 'Skills for growing up': supporting autonomy in young people with kidney disease. J Ren Care, 40 (2014), pp. 131139 
Sattoe, J.N.T., Bal, M.I., Roelofs, P.D.D.M., Bal, R., Miedema, H.S., Staa, A. van. Self-management interventions for young people with chronic conditions: a systematic overview. Patient Education and Counseling: 2015, 98(6), 704-715

\section{BOX, TABLE, FIGUUR}

Box 1: Search strategy in Embase

(('self care'/de OR 'self medication'/de OR 'self help'/de OR 'drug self administration'/de OR (((self OR shared) NEAR/3 (manag* OR care* OR medicat* OR efficac* OR help*))):ab,ti) OR ((('coping behavior'/exp OR 'health education'/de OR 'patient education'/de OR emotion/de OR emotionality/de) AND ('intervention study'/de OR psychotherapy/exp OR 'program development'/de)) OR (psychotherap* OR ((coping OR cope OR cognitiv* OR behavio* OR emotion* OR education* OR psychologic*) NEAR/6 (therap* OR interven* OR program*))):ab,ti)) AND ('chronic disease'/de OR 'genetic and familial disorders'/exp OR 'congenital disorder'/exp OR 'disabled person'/de OR 'handicapped child'/de OR disability/exp OR (((chronic* OR longterm OR 'long term' OR 'end stage' OR endstage* OR degenerat* OR persisten* OR genetic* OR familial* OR congenit*) NEAR/3 (ill* OR disease* OR condition* OR disorder*)) OR (physic* NEAR/3 (handicap* OR disab* OR challeng*))):de,ab,ti) AND (child/exp OR adolescent/exp OR adolescence/exp OR 'child health care'/de OR 'child care'/de OR 'child hospitalization'/de OR 'handicapped child'/de OR (young OR youth OR child* OR adolescen* OR teenage* OR teen OR teens OR juvenile*):ab,ti) AND ('comparative effectiveness'/de OR 'clinical effectiveness'/de OR evaluation/de OR 'self evaluation'/de OR (effectiv* OR evaluat*):ab,ti)

Fig. 1. Selection process.

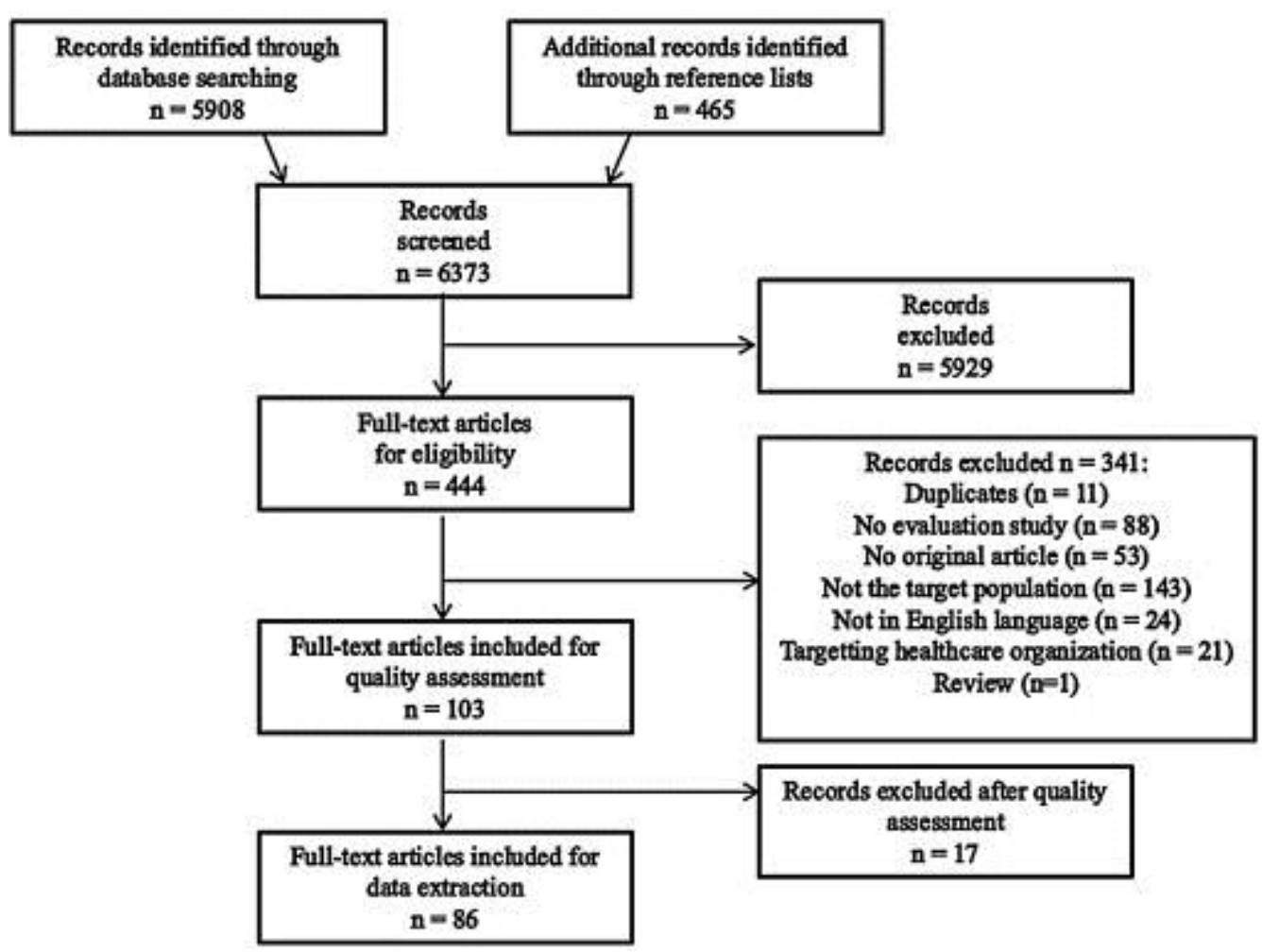


Sattoe, J.N.T., Bal, M.I., Roelofs, P.D.D.M., Bal, R., Miedema, H.S., Staa, A. van. Self-management interventions for young people with chronic conditions: a systematic overview. Patient Education and Counseling: 2015, 98(6), 704-715

Table 1. Studies by chronic condition $(n=86)$.

\begin{tabular}{|l|l|l|}
\hline \multicolumn{1}{|c|}{ Chronic condition } & \multicolumn{1}{c|}{ References } & \multicolumn{1}{c|}{ No. $(\%)$} \\
\hline Asthma & {$[26-43]$} & $18(20.9)$ \\
\hline Diabetes & {$[44-59]$} & $16(18.6)$ \\
\hline Cancer & {$[60-64]$} & $5(5.8)$ \\
\hline Chronic fatigue syndrome & {$[65]$} & $1(1.2)$ \\
\hline Chronic condition (various) & {$[66-71]$} & $6(7.0)$ \\
\hline Chronic pain & {$[72-76]$} & $5(5.8)$ \\
\hline Chronic respiratory condition & {$[77]$} & $1(1.2)$ \\
\hline Cystic fibrosis & {$[78-81]$} & $4(4.7)$ \\
\hline Eczema (atopic dermatitis) & {$[82]$} & $1(1.2)$ \\
\hline End-stage renal disease & {$[83-85]$} & $3(3.5)$ \\
\hline Epilepsy & {$[86]$} & $1(1.2)$ \\
\hline Heart disease & {$[87]$} & $1(1.2)$ \\
\hline Hiv & {$[88,89]$} & $2(2.3)$ \\
\hline Inflammatory bowel disease & {$[90]$} & $1(1.2)$ \\
\hline Ichthyosis & {$[91]$} & $1(1.2)$ \\
\hline Juvenile fibromyalgia & {$[92-94]$} & $3(3.5)$ \\
\hline Juvenile idiopathic arthritis & {$[95-98]$} & $4(4.7)$ \\
\hline Migraine & {$[99]$} & $1(1.2)$ \\
\hline Phenylketonuria & {$[100]$} & $1(1.2)$ \\
\hline Physical disability & {$[101-103]$} & $3(3.5)$ \\
\hline Sickle cell disease & {$[104-108]$} & $5(5.8)$ \\
\hline Spina bifida & {$[109-111]$} & $3(3.5)$ \\
\hline & & \\
\hline
\end{tabular}

Table 2. Formats and elements of self-management interventions according to mode.

\begin{tabular}{|c|c|c|}
\hline Modes & Formats & Elements \\
\hline \multirow{6}{*}{ Individual } & $\begin{array}{l}\text { Educational sessions (with or without } \\
\text { parents) or written materials }\end{array}$ & $\begin{array}{l}\text { - Informational (comic) books and videos } \\
\text { - Daily diaries or notebooks (with or without rewards) } \\
\text { - Homework assignments (written or skills practice) or workbook } \\
\text { - Check-in or booster telephone calls by interventionist } \\
\text { - Role reversal (between educator and the one(s) being educated) }\end{array}$ \\
\hline & Motivational interviewing sessions & $\begin{array}{l}\text { - Awareness building } \\
\text { - Problem solving } \\
\text { - Goal setting }\end{array}$ \\
\hline & (Skills) training sessions & $\begin{array}{l}\text { - Symptom treatment (e.g. relaxation techniques or pain provocation } \\
\text { technique) }\end{array}$ \\
\hline & $\begin{array}{l}\text { Cognitive behavioral therapy sessions } \\
\text { (some of them with parents) }\end{array}$ & $\begin{array}{l}\text { - Educational and skills training } \\
\text { - Instructions for home practice }\end{array}$ \\
\hline & Family sessions & $\begin{array}{l}\text { - Written materials } \\
\text { - Responsibility-sharing plan } \\
\text { - Family discussions (with conflict resolution) } \\
\text { - Problem solving training } \\
\text { - Communication training } \\
\text { - Homework assignments (behavior) }\end{array}$ \\
\hline & $\begin{array}{l}\text { Telemedicine system (e.g. through } \\
\text { personal devices, text-messaging, }\end{array}$ & $\begin{array}{l}\text { - Monitoring through daily diaries } \\
\text { - Overview of (trends in) disease-specific outcomes }\end{array}$ \\
\hline
\end{tabular}


Sattoe, J.N.T., Bal, M.I., Roelofs, P.D.D.M., Bal, R., Miedema, H.S., Staa, A. van. Self-management interventions for young people with chronic conditions: a systematic overview. Patient

Education and Counseling: 2015, 98(6), 704-715

\begin{tabular}{|c|c|c|}
\hline Modes & Formats & Elements \\
\hline & websites, or web-based systems) & $\begin{array}{l}\text { - Individualized feedback } \\
\text { - Reminders or cueing } \\
\text { - Social media communication or online discussion board } \\
\text { - 'Gamification' (with feedback or rewards), role-playing or } \\
\text { knowledge quizzes }\end{array}$ \\
\hline & $\begin{array}{l}\text { Telemedicine system (e.g. through } \\
\text { personal devices, text-messaging, } \\
\text { websites, or web-based systems) }\end{array}$ & $\begin{array}{l}\text { - Goal-setting or action plans } \\
\text { - Information messages, animated lessons or tips } \\
\text { - Skills training } \\
\text { - Modules with homework } \\
\text { - Possibility to contact healthcare provider } \\
\end{array}$ \\
\hline & CD-ROM & $\begin{array}{l}\text { - Educational modules } \\
\text { - Active coping plan } \\
\text { - 'Gamification' with feedback }\end{array}$ \\
\hline & $\begin{array}{l}\text { Peer-support (e.g. befriending } \\
\text { program) }\end{array}$ & - Mentorship \\
\hline & Individual (transition) plan & $\begin{array}{l}\text { - Age and developmentally appropriate information resources } \\
\text { - Goal-setting }\end{array}$ \\
\hline \multirow{8}{*}{ Group } & Cognitive behavioral therapy sessions & $\begin{array}{l}\text { - Fun activities and games or role-playing } \\
\text { - Homework (skills practice) } \\
\text { - Involvement of parents as coaches } \\
\text { - Goal-setting }\end{array}$ \\
\hline & Art therapy sessions & $\begin{array}{l}\text { - Discussion of weekly topics } \\
\text { - Art making } \\
\text { - Discussing art and related feelings }\end{array}$ \\
\hline & Camping programs & $\begin{array}{l}\text { - Traditional camping activities (e.g. horse riding, boating, arts etc.) } \\
\text { - Disease specific activities (e.g. educational sessions, support } \\
\text { groups, discussions, problem solving, role-playing, knowledge- } \\
\text { testing games) }\end{array}$ \\
\hline & Skills training or workshop & $\begin{array}{l}\text { - Goal assessment and goal-setting } \\
\text { - Drafting action or transition plans }\end{array}$ \\
\hline & Skills training or workshop & $\begin{array}{l}\text { - Practicing strategies for goal achievement (e.g. through role- } \\
\text { playing, coaching, use of audio-visual aids, accessing the Internet } \\
\text { etc.) }\end{array}$ \\
\hline & Educational and/or support sessions & $\begin{array}{l}\text { - Informational videos, (coloring) books, written information, } \\
\text { educational stories } \\
\text { - Didactic presentations } \\
\text { - Question and answer sessions } \\
\text { - Discussions and problem solving } \\
\text { - Homework assignments, exercise books and skills practice } \\
\text { - Self-monitoring with contingency management } \\
\text { - Self-management plans } \\
\text { - Devices for self-monitoring (e.g. peak flow meter) } \\
\text { - Peer education } \\
\text { - Sharing experiences }\end{array}$ \\
\hline & $\begin{array}{l}\text { Family sessions (parallel but separate } \\
\text { groups for children and parents; in } \\
\text { some cases one mixed session) }\end{array}$ & $\begin{array}{l}\text { - Play therapy, narrative therapy or role play } \\
\text { - Relaxation training } \\
\text { - Group work } \\
\text { - Social support } \\
\text { - Training in coping strategies } \\
\text { - Homework (practice skills) }\end{array}$ \\
\hline & $\begin{array}{l}\text { School program (with continued phone } \\
\text { contact) }\end{array}$ & $\begin{array}{l}\text { - Didactic presentation about the disease } \\
\text { - Peer education }\end{array}$ \\
\hline
\end{tabular}


Sattoe, J.N.T., Bal, M.I., Roelofs, P.D.D.M., Bal, R., Miedema, H.S., Staa, A. van. Self-management interventions for young people with chronic conditions: a systematic overview. Patient

Education and Counseling: 2015, 98(6), 704-715

Table 3. Content of interventions categorized by the domains of self-managementa.

\begin{tabular}{|c|c|c|}
\hline Domains $^{\mathrm{b}}$ & Content of interventions & References \\
\hline Medical management & $\begin{array}{l}\text { Disease-specific: } \\
\text { 1. Understanding the disease } \\
\text { 2. Understanding (the necessity of) medication and treatment } \\
\text { regimen; understanding side effects; adherence } \\
\text { 3. About the use of specific treatment devices or techniques } \\
\text { (e.g. peak flow meter for asthma) } \\
\text { 4. Dealing with symptoms } \\
\text { 5. Drafting an individualized care plan } \\
\text { 6. Self-monitoring of clinical outcomes } \\
\text { General: } \\
\text { 7. Accessing healthcare } \\
\text { 8. Communication with healthcare professionals } \\
\text { 9. Managing doctor visits } \\
\text { 10. Coping with hospitalizations } \\
\text { 11. Goals and dreams for the future related to health and } \\
\text { healthcare (transition) } \\
\text { 12. Child-parent sharing/teamwork related to disease-specific } \\
\text { medical management } \\
\text { 13. Knowing where to find specific information about the } \\
\text { disease } \\
\text { 14. Knowing when to ask for (medical) help } \\
\text { 15. Risk behavior (e.g. unsafe sex or drug and alcohol abuse) } \\
\text { [33,39,44,47,50,54,65,76,82,84,85,89,92,96,98,103,105,110] }\end{array}$ & $\mid \begin{array}{l}{[27,30-50,52-} \\
57,59,60,63,64,66,73- \\
76,79,82-85,87,90- \\
93,96,100,101,105-109]\end{array}$ \\
\hline Emotion management & $\begin{array}{l}\text { 1. Social initiation and friendship making; social networks; family } \\
\text { and romantic relationships } \\
\text { 2. Managing teasing and bullying; conflict resolution } \\
\text { 3. Participating in normal social activities; keeping up with } \\
\text { peers; Internet and social media } \\
\text { 4. Goals and dreams for the future related to school, work, } \\
\text { community, living, housing, recreation and leisure (looking } \\
\text { ahead); school issues } \\
\text { 5. Romantic relationships and sexuality } \\
\text { 6. Explaining the condition to others (disclosure); educating } \\
\text { peers } \\
\text { 7. Setting (life) goals and becoming assertive; growing up } \\
\text { 8. Communication and social problem solving (sometimes } \\
\text { within families); organizational skills } \\
\text { 9. Independent living; traveling/staying abroad } \\
\text { 10. Social rights and benefits } \\
\text { 1. Self-confidence or self-esteem building; developing a positive } \\
\text { body image; body esteem } \\
\text { 2. Self-appreciation; enhancing hope; enhancing self-efficacy } \\
\text { 3. Empathy; fear-related thinking; } \\
\text { 4. Feelings related to condition; sharing of feelings and } \\
\text { experiences } \\
\text { 5. Accepting condition; self-reflection } \\
\text { 6. Healthy expressions of anger and transforming or managing } \\
\text { anger } \\
\text { 7. Helpful/positive thoughts; stress management } \\
\text { 8. Decreasing negative thoughts } \\
\text { 9. Decreasing stress and boredom; decreasing social isolation } \\
\text { 10. Spirituality } \\
\text { 11. Emotions }\end{array}$ & $\begin{array}{l}{[29,40,42,47,49,51,59,61,6} \\
2,65- \\
67,70,71,74,76,80,83,86 \\
87,96,99,100,103,104,11 \\
1]\end{array}$ \\
\hline
\end{tabular}

${ }^{\mathrm{A}}$ Number of studies is 78 , three studies were unclear about the content of the intervention: $[58,68,88]$.

${ }^{B}$ According to the model of Lorig \& Holman (2003) [14]. 
Sattoe, J.N.T., Bal, M.I., Roelofs, P.D.D.M., Bal, R., Miedema, H.S., Staa, A. van. Self-management interventions for young people with chronic conditions: a systematic overview. Patient Education and Counseling: 2015, 98(6), 704-715

Fig. 2. Distribution of interventions $(n=78)$ over (combinations of) self-management domains. MM - medical management, $\mathrm{RM}$ - role management, $\mathrm{EM}$ - emotion management

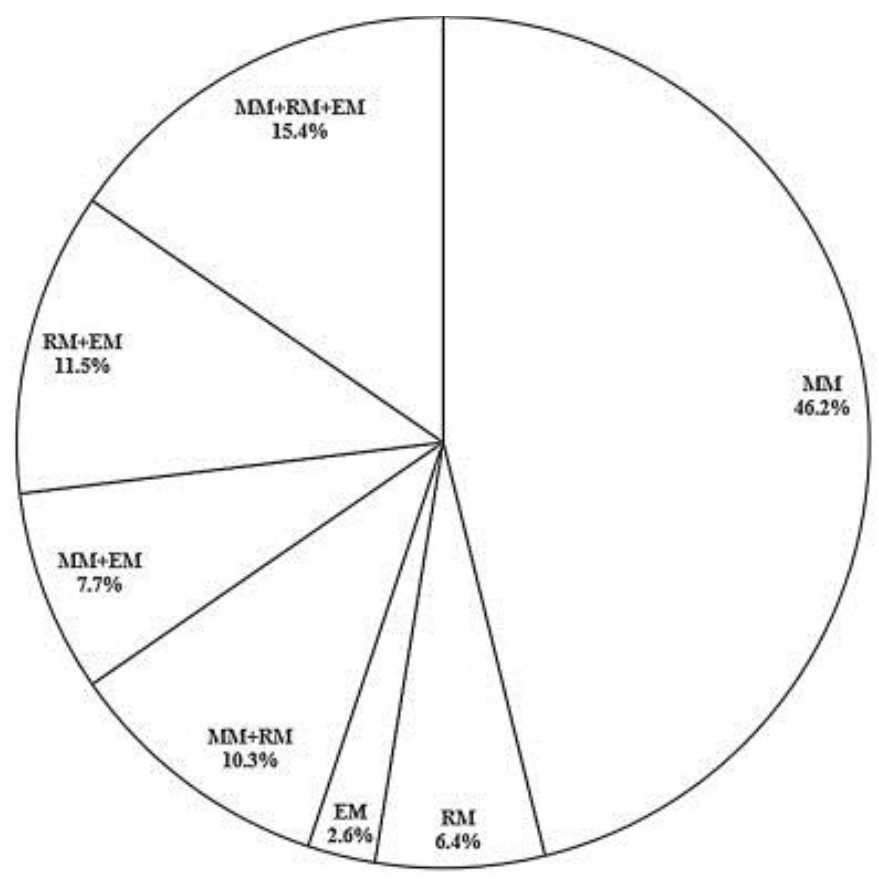

Table 4. Theoretical bases of self-management interventions, no. (\%).

\begin{tabular}{|c|c|c|}
\hline Theoretical base & $\begin{array}{l}\text { Number of } \\
\text { interventions }(n=26)\end{array}$ & References \\
\hline $\begin{array}{l}\text { (Cognitive) social learning } \\
\text { theory }\end{array}$ & $10(38.5)$ & {$[29,31,48,51,59,65,75,76,79,89]$} \\
\hline Cognitive behavioral theory & $9(34.6)$ & {$[64,66,70,74,75,91,93,106,109]$} \\
\hline Health belief model & $2(7.7)$ & {$[35,85]$} \\
\hline $\begin{array}{l}\text { Prochaska's transtheoretical } \\
\text { model }\end{array}$ & $1(3.8)$ & {$[35]$} \\
\hline $\begin{array}{l}\text { Self-regulation model of } \\
\text { health and illness }\end{array}$ & $1(3.8)$ & {$[65]$} \\
\hline $\begin{array}{l}\text { Transactional model of } \\
\text { stress }\end{array}$ & $1(3.8)$ & {$[40]$} \\
\hline $\begin{array}{l}\text { Orem's self-care deficit } \\
\text { theory of nursing }\end{array}$ & $2(7.7)$ & {$[39,44]$} \\
\hline $\begin{array}{l}\text { Game-playing and health } \\
\text { theory }\end{array}$ & $1(3.8)$ & {$[108]$} \\
\hline Flirt model & $1(3.8)$ & {$[67]$} \\
\hline Self-confrontation & $1(3.8)$ & [99] \\
\hline Model of human occupation & $1(3.8)$ & {$[104]$} \\
\hline
\end{tabular}


Sattoe, J.N.T., Bal, M.I., Roelofs, P.D.D.M., Bal, R., Miedema, H.S., Staa, A. van. Self-management interventions for young people with chronic conditions: a systematic overview. Patient

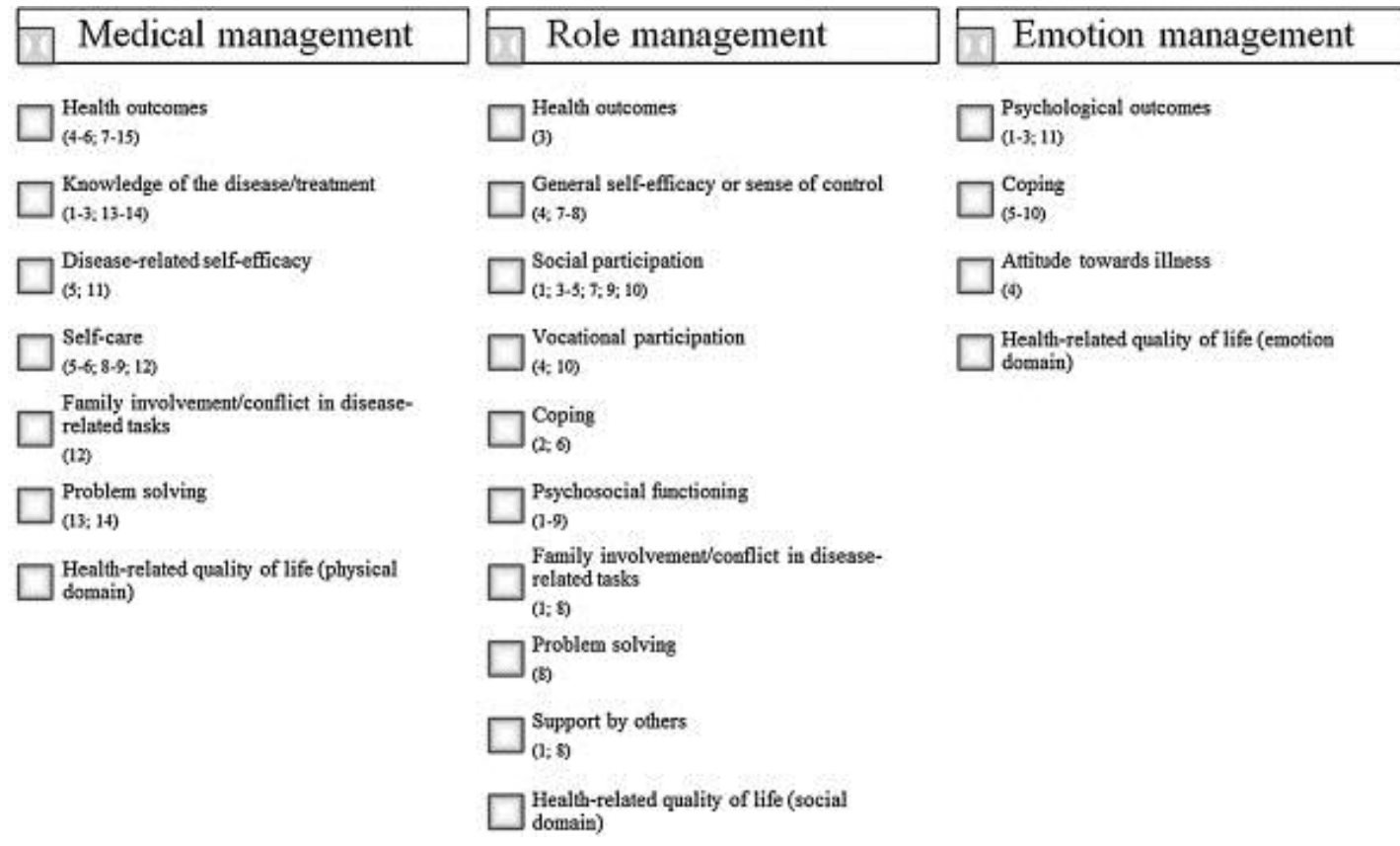

Table 5. Outcomes used in the evaluation studies distributed over (combinations of) self-management domains.

\begin{tabular}{|c|c|c|c|c|c|c|c|c|}
\hline \begin{tabular}{|c|} 
(Combined) \\
domains of self- \\
management $^{\mathrm{a}}$ \\
No. $(\%$ of total \\
studies $\left.{ }^{\mathrm{b}}\right)$ \\
Groups of \\
outcome \\
constructs or $^{\text {onemes }}{ }^{\mathrm{c}}$ \\
them $^{\mathrm{s}}$
\end{tabular} & $\begin{array}{c}\mathrm{MM} n=36 \\
\quad(46.2)\end{array}$ & $\underset{(6.4)}{\operatorname{RM} n=5}$ & $\begin{array}{c}\mathrm{EM} n=2 \\
\quad(2.6)\end{array}$ & $\begin{array}{c}\mathrm{MM}+\mathrm{R} \\
\mathrm{M} n=8 \\
(\mathbf{1 0 . 3})\end{array}$ & $\begin{array}{c}\mathrm{MM}+\mathrm{EM} \\
n=6(7.7)\end{array}$ & $\begin{array}{c}\mathrm{RM}+\mathrm{EM} \\
n=9(11.5)\end{array}$ & $\begin{array}{c}\mathrm{MM}+\mathrm{RM}+ \\
\mathrm{EM} n=12 \\
(15.4)\end{array}$ & $\begin{array}{c}\text { Totalb } n=7 \\
8\end{array}$ \\
\hline Health outcomes & $27(75.0)$ & $2(40.0)$ & & $4(50.0)$ & $5(83.3)$ & $3(33.3)$ & $7(58.3)$ & $48(61.5)$ \\
\hline $\begin{array}{l}\text { Health-related } \\
\text { quality of life }\end{array}$ & $13(36.1)$ & & & $5(62.5)$ & $1(16.7)$ & $4(44.4)$ & $5(41.7)$ & $28(35.9)$ \\
\hline $\begin{array}{l}\text { Knowledge of } \\
\text { disease/treatment }\end{array}$ & $12(33.3)$ & & $1(50.0)$ & $6(75.0)$ & & $2(22.2)$ & $2(16.7)$ & $23(29.5)$ \\
\hline $\begin{array}{l}\text { Psychological } \\
\text { outcomes }\end{array}$ & $7(19.4)$ & & & $1(12.5)$ & $1(16.7)$ & $5(55.6)$ & $2(16.7)$ & $16(20.5)$ \\
\hline Self-efficacy & $8(22.2)$ & & & $3(37.5)$ & & $2(22.2)$ & $2(16.7)$ & $15(19.2)$ \\
\hline $\begin{array}{l}\text { Vocational } \\
\text { participation }\end{array}$ & $5(13.8)$ & & & $2(25.0)$ & $1(16.7)$ & $2(22.2)$ & $2(16.7)$ & $12(15.4)$ \\
\hline $\begin{array}{l}\text { Social } \\
\text { participation }\end{array}$ & $2(5.6)$ & $1(20.0)$ & $1(50.0)$ & $1(12.5)$ & & $5(55.6)$ & $2(16.7)$ & $12(15.4)$ \\
\hline Coping & $1(2.8)$ & & & $1(12.5)$ & $2(33.3)$ & $3(33.3)$ & $1(8.3)$ & $8(10.3)$ \\
\hline Self-care & $2(5.6)$ & & & $3(37.5)$ & & & $2(16.7)$ & $7(9.0)$ \\
\hline \begin{tabular}{|l|} 
Psychosocial \\
functioning \\
Family \\
involvement or \\
conflict (related \\
to disease-related \\
management
\end{tabular} & $4(11.1)$ & $2(40.0)$ & & $1(12.5)$ & $1(16.7)$ & $1(11.1)$ & $2(16.7)$ & $6(7.7)$ \\
\hline
\end{tabular}


Sattoe, J.N.T., Bal, M.I., Roelofs, P.D.D.M., Bal, R., Miedema, H.S., Staa, A. van. Self-management interventions for young people with chronic conditions: a systematic overview. Patient Education and Counseling: 2015, 98(6), 704-715

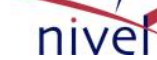

\begin{tabular}{|c|c|c|c|c|c|c|c|c|}
\hline \begin{tabular}{|c} 
Combined $)$ \\
domains of self- $^{\text {management }}{ }^{\mathrm{a}}$ \\
No. $\left(\%\right.$ of total $\left.^{\text {studies }}{ }^{\mathrm{b}}\right)$ \\
Groups of \\
outcome \\
constructs or $^{\text {themes }}{ }^{\mathrm{c}}$ \\
\end{tabular} & $\begin{array}{c}\mathrm{MM} n=36 \\
\quad(46.2)\end{array}$ & $\underset{(6.4)}{\operatorname{RM} n=5}$ & $\begin{array}{c}\operatorname{EM} n=2 \\
\quad(2.6)\end{array}$ & $\begin{array}{c}\mathrm{MM}+\mathrm{R} \\
\mathrm{M} n=\mathbf{8} \\
(\mathbf{1 0 . 3 )}\end{array}$ & $\begin{array}{c}M M+E M \\
n=6(7.7)\end{array}$ & $\begin{array}{c}\text { RM }+ \text { EM } \\
n=9(11.5)\end{array}$ & $\begin{array}{c}\mathrm{MM}+\mathrm{RM}+ \\
\mathrm{EM} n=12 \\
(15.4)\end{array}$ & $\begin{array}{c}\text { Totalb } n=7 \\
8\end{array}$ \\
\hline tasks) & & & & & & & & \\
\hline Sense of control & $1(2.8)$ & & & $2(25.0)$ & & & & $3(3.8)$ \\
\hline $\begin{array}{l}\text { Attitudes } \\
\text { towards illness }\end{array}$ & $2(5.6)$ & & & $1(12.5)$ & & $1(11.1)$ & & $3(3.8)$ \\
\hline $\begin{array}{l}\text { Self-perception } \\
\text { of competencies }\end{array}$ & $1(3.1)$ & & & $1(14.3)$ & & & & $2(2.6)$ \\
\hline Problem solving & $2(6.3)$ & & & & & & & $2(2.6)$ \\
\hline $\begin{array}{l}\text { Support by } \\
\text { others }\end{array}$ & & & $1(50.0)$ & & & & $1(9.1)$ & $2(2.6)$ \\
\hline
\end{tabular}

${ }^{A}$ According to the model of Lorig \& Holman (2003) [14]: $\mathrm{MM}=$ medical management, $\mathrm{RM}=$ role management, $\mathrm{EM}=$ emotion management.

${ }^{B}$ Number of studies is 78 , three studies were unclear about the content of the intervention: $[58,68,88]$.

${ }^{\mathrm{C}}$ Only measured in young people (e.g., no parent proxy measures). 
Sattoe, J.N.T., Bal, M.I., Roelofs, P.D.D.M., Bal, R., Miedema, H.S., Staa, A. van. Self-management interventions for young people with chronic conditions: a systematic overview. Patient Education and Counseling: 2015, 98(6), 704-715

Fig. 3. A content-based framework for the selection of (groups of) outcome measures. The numbers presented next to the outcomes correspond to specific content in Table 3.

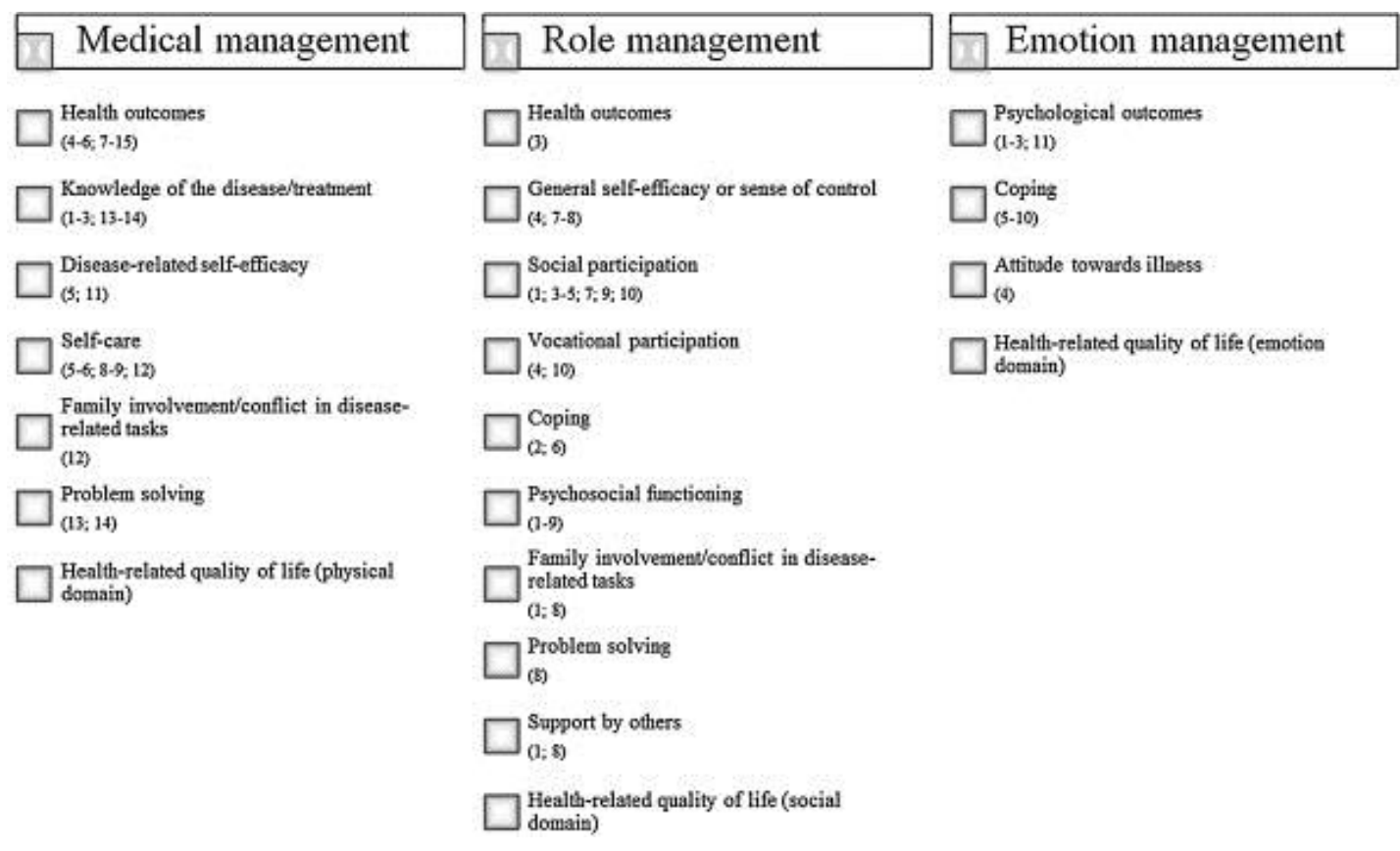


Appendix A:

Table A.1 Overview of study and intervention characteristics

Table A.2 Overview of outcome measures used in the evaluation studies 
Table A.1 Overview of study and intervention characteristics $(n=86)^{\star}$

\begin{tabular}{|c|c|c|c|c|c|c|c|c|c|c|c|c|}
\hline \multicolumn{3}{|c|}{ Study characteristics } & \multicolumn{2}{|c|}{ Participants } & \multicolumn{8}{|c|}{ Intervention characteristics } \\
\hline Identifier & Country & Design & Condition & $\begin{array}{l}\text { Mean age } \\
\text { or age } \\
\text { range (in } \\
\text { years) }\end{array}$ & Mode & $\begin{array}{l}\text { Delivery } \\
\text { location }\end{array}$ & $\begin{array}{l}\text { Interventi } \\
\text { onists }\end{array}$ & Format(s) & Element(s) & Timing & $\begin{array}{l}\text { Domain(s) } \\
\text { of SM }\end{array}$ & $\begin{array}{l}\text { Theoret } \\
\text { ical } \\
\text { base }\end{array}$ \\
\hline $\begin{array}{l}\text { Barakat et } \\
\text { al. } 2010\end{array}$ & $\begin{array}{l}\text { United } \\
\text { States of } \\
\text { America }\end{array}$ & RCT & $\begin{array}{l}\text { Sickle cell } \\
\text { disease }\end{array}$ & 14.1 & $\begin{array}{l}\text { Individ } \\
\text { ual }\end{array}$ & $\begin{array}{l}\text { Home } \\
\text { environme } \\
\text { nt }\end{array}$ & $\begin{array}{l}\text { Doctoral } \\
\text { students } \\
\text { in clinical } \\
\text { psycholog } \\
\text { y or } \\
\text { psychologi } \\
\text { sts }\end{array}$ & $\begin{array}{l}\text { Educational } \\
\text { sessions }\end{array}$ & $\begin{array}{l}\text { Daily paper-and- } \\
\text { pencil pain diaries, } \\
\text { homework, review } \\
\text { of homework, and } \\
\text { biweekly check-in } \\
\text { telephone calls }\end{array}$ & $\begin{array}{l}\text { Sessions take } 90 \\
\text { minutes. } \\
\text { Intervention: } 4 \\
\text { sessions ( } 3 \\
\text { sessions, } 2 \text { weeks } \\
\text { apart with a booster } \\
\text { session } 1 \text { month } \\
\text { later) } \\
\end{array}$ & $\overline{M M}$ & $N A^{\star \star}$ \\
\hline $\begin{array}{l}\text { Barrera \& } \\
\text { Schulte } \\
2009\end{array}$ & Canada & Cohort & Cancer & 12.7 & Group & $\begin{array}{l}\text { Clinic } \\
\text { (Pediatric } \\
\text { center) }\end{array}$ & $\begin{array}{l}\text { Psycholog } \\
\text { ist, and } \\
\text { clinical } \\
\text { assistants }\end{array}$ & $\begin{array}{l}\text { Skills training } \\
\text { sessions }\end{array}$ & $\begin{array}{l}\text { Fun activities and } \\
\text { games guided by } \\
\text { cognitive behavior } \\
\text { strategies and } \\
\text { expressive } \\
\text { therapies such as } \\
\text { music, art, and } \\
\text { drama. }\end{array}$ & $\begin{array}{l}\text { A 2-hr group session } \\
\text { once a week for } 8 \\
\text { weeks. }\end{array}$ & RM and EM & NA \\
\hline $\begin{array}{l}\text { Beebe et } \\
\text { al. } 2010\end{array}$ & $\begin{array}{l}\text { United } \\
\text { States of } \\
\text { America }\end{array}$ & RCT & Astma & $7-14$ & Group & School & NA & $\begin{array}{l}\text { Art therapy } \\
\text { sessions }\end{array}$ & $\begin{array}{l}\text { Art making, and } \\
\text { sharing feelings } \\
\text { related to the art } \\
\text { created. }\end{array}$ & $\begin{array}{l}\text { A 1- hour session for } \\
7 \text { weeks. }\end{array}$ & $\mathrm{MM}$ and $\mathrm{EM}$ & NA \\
\hline $\begin{array}{l}\text { Bekesi et } \\
\text { al. } 2011\end{array}$ & Hungary & Cohort & $\begin{array}{l}\text { Oncology, } \\
\text { diabetes, } \\
\text { juvenile } \\
\text { immune } \\
\text { arthritis }\end{array}$ & 13.3 & Group & $\begin{array}{l}\text { Camp, } \\
\text { and clinic } \\
\text { (medical } \\
\text { centre) }\end{array}$ & $\begin{array}{l}\text { Volunteer } \\
\text { s } \\
\text { (selected } \\
\text { and } \\
\text { trained, } \\
\text { profession } \\
\text { not } \\
\text { mentioned } \\
\text { ) }\end{array}$ & $\begin{array}{l}\text { Camping } \\
\text { program }\end{array}$ & $\begin{array}{l}\text { Adventure-based } \\
\text { program with } \\
\text { activities and fun. }\end{array}$ & $\mathrm{NA}$ & $\mathrm{RM}$ & NA \\
\hline $\begin{array}{l}\text { Berrien et } \\
\text { al. } 2004\end{array}$ & $\begin{array}{l}\text { United } \\
\text { States of } \\
\text { America }\end{array}$ & RCT & HIV & 10.0 & $\begin{array}{l}\text { Individ } \\
\text { ual } \\
\text { home } \\
\text { visit }\end{array}$ & Home & $\begin{array}{l}\text { Experienc } \\
\text { ed } \\
\text { registered } \\
\text { nurse }\end{array}$ & $\begin{array}{l}\text { Educational } \\
\text { sessions }\end{array}$ & $\begin{array}{l}\text { A comic book, a } \\
\text { video, filling out } \\
\text { notebooks with } \\
\text { rewards (prizes) if } \\
\text { they did, and } \\
\text { eventually role } \\
\text { reversal. }\end{array}$ & $\mathrm{NA}$ & MM & NA \\
\hline
\end{tabular}




\begin{tabular}{|c|c|c|c|c|c|c|c|c|c|c|c|c|}
\hline $\begin{array}{l}\text { Betz et al. } \\
2011\end{array}$ & $\begin{array}{l}\text { United } \\
\text { States of } \\
\text { America }\end{array}$ & RCT & Spina Bifida & 16.0 & Group & Clinic & \begin{tabular}{|l} 
Trainer \\
(not \\
mentioned \\
if this was \\
a \\
healthcare \\
profession \\
al)
\end{tabular} & $\begin{array}{l}\text { Skills training } \\
\text { sessions }\end{array}$ & $\begin{array}{l}\text { Making a transition } \\
\text { plan, and } \\
\text { practicing } \\
\text { strategies to obtain } \\
\text { goals, i.e. role } \\
\text { playing, one-to-one } \\
\text { consultation, } \\
\text { coaching, } \\
\text { reinforced learning, } \\
\text { use of audio visual } \\
\text { aids, accessing the } \\
\text { Internet, and } \\
\text { mentored learning. }\end{array}$ & 2-day workshop & MM and RM & NA \\
\hline $\begin{array}{l}\text { Bultas et } \\
\text { al. } 2013\end{array}$ & $\begin{array}{l}\text { United } \\
\text { States of } \\
\text { America }\end{array}$ & Cohort & \begin{tabular}{|l} 
Heart \\
disease
\end{tabular} & $8-15$ & Group & Camp & \begin{tabular}{|l|} 
Pediatric \\
nurses \\
and \\
cardiologi \\
sts
\end{tabular} & NA & NA & 5 days and 4 nights & NA & NA \\
\hline $\begin{array}{l}\text { Burkhart et } \\
\text { al. } 2007\end{array}$ & $\begin{array}{l}\text { United } \\
\text { States of } \\
\text { America }\end{array}$ & $\mathrm{RCT}$ & Asthma & $7-12$ & $\begin{array}{l}\text { Group } \\
\text { sessio } \\
\text { ns }\end{array}$ & $\begin{array}{l}\text { Clinic } \\
\text { (university } \\
\text { center for } \\
\text { nursing } \\
\text { reserach) }\end{array}$ & $\begin{array}{l}\text { Research } \\
\text { associate }\end{array}$ & $\begin{array}{l}\text { Educational } \\
\text { sessions }\end{array}$ & $\begin{array}{l}\text { Educational } \\
\text { videos, and } \\
\text { homework } \\
\text { assignments }\end{array}$ & $\mathrm{NA}$ & $\mathrm{MM}$ & $\begin{array}{l}\text { (Cogniti } \\
\text { ve) } \\
\text { social } \\
\text { learning } \\
\text { theory }\end{array}$ \\
\hline $\begin{array}{l}\text { Butz et al. } \\
2005\end{array}$ & $\begin{array}{l}\text { United } \\
\text { States of } \\
\text { America }\end{array}$ & RCT & Asthma & 8.0 & $\begin{array}{l}\text { Group } \\
\text { sessio } \\
\text { ns }\end{array}$ & School & \begin{tabular}{|l} 
Asthma \\
educator \\
(not \\
mentioned \\
if this was \\
a \\
healthcare \\
profession \\
al)
\end{tabular} & $\begin{array}{l}\text { Skills training } \\
\text { sessions }\end{array}$ & $\begin{array}{l}\text { Practiced and } \\
\text { demonstrated } \\
\text { specific skills (peak } \\
\text { flow meter and } \\
\text { inhaler technique). } \\
\text { Discussions with } \\
\text { the educator, and a } \\
\text { coloring book, a } \\
\text { peak flow meter, } \\
\text { and a spacer } \\
\text { device were given } \\
\text { to children. }\end{array}$ & $\begin{array}{l}4 \text { hours of instruction } \\
\text { during two seperate } \\
\text { sessions }\end{array}$ & MM & $\mathrm{NA}$ \\
\hline
\end{tabular}




\begin{tabular}{|c|c|c|c|c|c|c|c|c|c|c|c|c|}
\hline $\begin{array}{l}\text { Cafazzo et } \\
\text { al. } 2012\end{array}$ & Canada & Cohort & | Diabetes & 14.9 & $\begin{array}{l}\text { Individ } \\
\text { ual }\end{array}$ & Online & Clinicians & $\begin{array}{l}\text { Telemanageme } \\
\text { nt system }\end{array}$ & $\begin{array}{l}\text { Reminders, cueing, } \\
\text { social media } \\
\text { communication, } \\
\text { and the } \\
\text { gamification of } \\
\text { routine } \\
\text { management } \\
\text { tasks. }\end{array}$ & NA & MM & NA \\
\hline $\begin{array}{l}\text { Canada et } \\
\text { al. } 2007\end{array}$ & $\begin{array}{l}\text { United } \\
\text { States of } \\
\text { America }\end{array}$ & Cohort & Cancer & 21.3 & \begin{tabular}{|l|} 
Individ \\
ual
\end{tabular} & Clinic & $\begin{array}{l}\text { Doctoral } \\
\text { level } \\
\text { clinical } \\
\text { psychologi } \\
\text { st }\end{array}$ & $\begin{array}{l}\text { Educational } \\
\text { (and support) } \\
\text { sessions }\end{array}$ & $\begin{array}{l}\text { Workbook, } \\
\text { homework, and } \\
\text { follow-up phone } \\
\text { calls }\end{array}$ & $\mathrm{NA}$ & RM and EM & NA \\
\hline $\begin{array}{l}\text { Channon } \\
\text { et al. } 2007\end{array}$ & \begin{tabular}{|l} 
United \\
Kingdom
\end{tabular} & RCT & Diabetes & 15.3 & $\begin{array}{l}\text { Individ } \\
\text { ual }\end{array}$ & Home & $\begin{array}{l}\text { Nurses, } \\
\text { and a } \\
\text { health } \\
\text { psychologi } \\
\text { st }\end{array}$ & $\begin{array}{l}\text { Motivational } \\
\text { interviewing } \\
\text { sessions }\end{array}$ & $\begin{array}{l}\text { Awareness } \\
\text { building, problem } \\
\text { solving, and goal- } \\
\text { setting. }\end{array}$ & $\begin{array}{l}\text { The frequency and } \\
\text { location of } \\
\text { appointments was } \\
\text { determined by the } \\
\text { participants to fit with } \\
\text { the patient- driven } \\
\text { principles of } \\
\text { motivational } \\
\text { interviewing. } \\
\text { Interviews lasts } \\
\text { between } 20 \text { and } 60 \\
\text { min. }\end{array}$ & NA & NA \\
\hline $\begin{array}{l}\text { Chiang et } \\
\text { al. } 2009\end{array}$ & Taiwan & RCT & Astma & $6-14$ & \begin{tabular}{|l|} 
Individ \\
ual
\end{tabular} & $\begin{array}{l}\text { Home, } \\
\text { and clinic }\end{array}$ & $\begin{array}{l}\text { Nursing } \\
\text { graduate } \\
\text { student }\end{array}$ & $\begin{array}{l}\text { Skills training } \\
\text { sessions }\end{array}$ & Relaxation training & $\begin{array}{l}\text { During the 12-week } \\
\text { intervention, } \\
\text { participants practiced } \\
\text { relaxation for } 30 \text { min } \\
\text { at least three times } \\
\text { per week. }\end{array}$ & MM & NA \\
\hline $\begin{array}{l}\text { Christian \& } \\
\text { D'Auria } \\
2006\end{array}$ & $\begin{array}{l}\text { United } \\
\text { States of } \\
\text { America }\end{array}$ & RCT & \begin{tabular}{|l} 
Cystic \\
Fibrosis
\end{tabular} & $8-12$ & \begin{tabular}{|l|} 
Individ \\
ual \\
home \\
visit, \\
and \\
group \\
sessio \\
n \\
\end{tabular} & $\begin{array}{l}\text { Home, } \\
\text { and clinic }\end{array}$ & NA & $\begin{array}{l}\text { Educational } \\
\text { sessions and } \\
\text { support } \\
\text { sessions }\end{array}$ & $\begin{array}{l}\text { A computer } \\
\text { software program, } \\
\text { a notebook with } \\
\text { worksheets, and a } \\
\text { journal (individual). } \\
\text { Discussion and } \\
\text { peer contact } \\
\text { (group). }\end{array}$ & NA & RM & NA \\
\hline
\end{tabular}




\begin{tabular}{|c|c|c|c|c|c|c|c|c|c|c|c|c|}
\hline $\begin{array}{l}\text { Clark et al. } \\
2004\end{array}$ & \begin{tabular}{|l} 
United \\
States of \\
America
\end{tabular} & RCT & Astma & |7-10 & Goup & School & NA & \begin{tabular}{|l} 
Educational \\
sessions
\end{tabular} & \begin{tabular}{|l|} 
Handouts and \\
homework \\
assignments, \\
group discussions, \\
asthma action plan
\end{tabular} & NA & MM & NA \\
\hline $\begin{array}{l}\text { Clark et al. } \\
2010\end{array}$ & \begin{tabular}{|l|} 
United \\
States of \\
America
\end{tabular} & RCT & Asthma & 11.9 & \begin{tabular}{|l} 
Group \\
lesson \\
s
\end{tabular} & School & \begin{tabular}{|l|} 
Graduate \\
students, \\
and \\
communit \\
y leaders \\
trained in \\
the \\
program \\
(professio \\
n not \\
mentioned \\
)
\end{tabular} & School program & \begin{tabular}{|l|} 
Interactive \\
problem-solving \\
activities. Peer \\
education \\
component (not \\
necessarily Asthma \\
patient) in which \\
peers educated \\
asthma awareness \\
to participants \\
through skits, \\
creative dramas or \\
music.
\end{tabular} & NA & $\begin{array}{l}\text { MM, RM } \\
\text { and EM }\end{array}$ & NA \\
\hline $\begin{array}{l}\text { Connelly et } \\
\text { al. } 2006\end{array}$ & $\begin{array}{l}\text { United } \\
\text { States of } \\
\text { America }\end{array}$ & RCT & Migraine & $7-12$ & \begin{tabular}{|l|} 
Individ \\
ual
\end{tabular} & Home & NA & CD-ROM & $\begin{array}{l}\text { Educational } \\
\text { modules, active } \\
\text { coping plan, and } \\
\text { gamification (with } \\
\text { feedback). }\end{array}$ & NA & MM and EM & NA \\
\hline $\begin{array}{l}\text { Creedy et } \\
\text { al. } 2004\end{array}$ & Australia & Cohort & \begin{tabular}{|l|} 
Various \\
chronic \\
conditions
\end{tabular} & \begin{tabular}{|l|l|}
$10-14$ \\
\end{tabular} & \begin{tabular}{|l|} 
Group \\
sessio \\
ns
\end{tabular} & NA & \begin{tabular}{|l} 
Graduates \\
of a \\
leadership \\
training \\
course co- \\
facilitated \\
the \\
interventio \\
$n$ with \\
healthcare \\
profession \\
als
\end{tabular} & \begin{tabular}{|l|} 
Family \\
sessions \\
(parallel but \\
seperate \\
sessions for \\
parents and \\
children).
\end{tabular} & Peer support & 8 weeks & $\mathrm{RM}$ and $\mathrm{EM}$ & NA \\
\hline
\end{tabular}




\begin{tabular}{|c|c|c|c|c|c|c|c|c|c|c|c|c|}
\hline $\begin{array}{l}\text { Curle et al. } \\
2005\end{array}$ & $\begin{array}{l}\text { United } \\
\text { States of } \\
\text { America }\end{array}$ & $\begin{array}{l}\text { Qualitati } \\
\text { ve }\end{array}$ & \begin{tabular}{|l} 
Various \\
chronic \\
conditions
\end{tabular} & |7-12 & $\begin{array}{l}\text { Group } \\
\text { sessio } \\
\text { ns }\end{array}$ & $\begin{array}{l}\text { Clinic } \\
\text { (specialize } \\
\text { d unit) }\end{array}$ & \begin{tabular}{|l} 
A clinical \\
psychologi \\
st, \\
occupatio \\
nal \\
therapist, \\
mental \\
health \\
nurses, \\
and \\
specialist \\
pedatric \\
nurses or \\
social \\
workers.
\end{tabular} & \begin{tabular}{|l} 
Family \\
sessions \\
(parallel but \\
seperate \\
sessions for \\
parents and \\
children).
\end{tabular} & $\begin{array}{l}\text { Play therapy, } \\
\text { narrative therapy, } \\
\text { relaxation training } \\
\text { and group work. }\end{array}$ & 6-8 sessions & EM & $\begin{array}{l}\text { Cognitiv } \\
\text { e } \\
\text { behavior } \\
\text { al } \\
\text { theory, } \\
\text { and } \\
\text { Systemi } \\
\text { c theory }\end{array}$ \\
\hline $\begin{array}{l}\text { Cushner- } \\
\text { Weinstein } \\
\text { et al. } 2007\end{array}$ & $\begin{array}{l}\text { United } \\
\text { States of } \\
\text { America }\end{array}$ & Cohort & Epilepsy & $7-17$ & $\begin{array}{l}\text { Group } \\
\text { sessio } \\
\text { ns }\end{array}$ & Camp & \begin{tabular}{|l} 
Medical \\
profession \\
als, and \\
counselin \\
g staff
\end{tabular} & $\begin{array}{l}\text { Camping } \\
\text { program }\end{array}$ & $\begin{array}{l}\text { Traditional camp } \\
\text { activities (rope } \\
\text { course, swimming, } \\
\text { arts, crafts etc.) } \\
\text { combined with } \\
\text { activities with } \\
\text { condition-specific } \\
\text { goals and } \\
\text { relevance, and } \\
\text { support groups } \\
\text { (peer contacts). } \\
\end{array}$ & 7 days & $\begin{array}{l}\mathrm{MM}, \mathrm{RM} \\
\text { and EM }\end{array}$ & $\mathrm{NA}$ \\
\hline $\begin{array}{l}\text { Davis et al. } \\
2004\end{array}$ & $\begin{array}{l}\text { United } \\
\text { States of } \\
\text { America }\end{array}$ & RCT & \begin{tabular}{|l} 
Cystic \\
Fibrosis
\end{tabular} & 7-17 & \begin{tabular}{|l} 
Individ \\
ual
\end{tabular} & Home & NA & CD-ROM & $\begin{array}{l}\text { Educational } \\
\text { modules }\end{array}$ & NA & $\begin{array}{l}\text { MM, RM } \\
\text { and EM }\end{array}$ & NA \\
\hline \begin{tabular}{|l|} 
Dobson \\
2014
\end{tabular} & $\begin{array}{l}\text { United } \\
\text { States of } \\
\text { America }\end{array}$ & Cohort & \begin{tabular}{|l|} 
Sickle cell \\
disease
\end{tabular} & $6-8$ & \begin{tabular}{|l|} 
Individ \\
ual
\end{tabular} & $\begin{array}{l}\text { Clinic and } \\
\text { home }\end{array}$ & $\begin{array}{l}\text { Child life } \\
\text { specialist }\end{array}$ & \begin{tabular}{|l} 
Diary and \\
guided \\
imagery, \\
including one \\
training session
\end{tabular} & $\begin{array}{l}\text { Participants kept a } \\
\text { diary, recording } \\
\text { their daily activities } \\
\text { and all pain } \\
\text { episodes, including } \\
\text { location and } \\
\text { intensity, as well as } \\
\text { strategies for } \\
\text { management. The } \\
\text { diaries included } \\
\text { blank daily pages } \\
\text { with the instruction, } \\
\text { "Use one page a }\end{array}$ & $\begin{array}{l}\text { The training sessions } \\
\text { lasted from 15-45 } \\
\text { minutes }\end{array}$ & MM & $\begin{array}{l}\text { Cognitiv } \\
\text { e } \\
\text { behavior } \\
\text { al } \\
\text { therapy }\end{array}$ \\
\hline
\end{tabular}




\begin{tabular}{|c|c|c|c|c|c|c|c|c|c|c|c|c|}
\hline & & & & & & & & & $\begin{array}{l}\text { day to describe } \\
\text { your activities and } \\
\text { your pain, and one } \\
\text { page to draw a } \\
\text { picture". } \\
\end{array}$ & & & \\
\hline $\begin{array}{l}\text { Downs et } \\
\text { al. } 2006\end{array}$ & Australia & RCT & $\begin{array}{l}\text { Cystic } \\
\text { Fibrosis }\end{array}$ & 8.4 & $\begin{array}{l}\text { Individ } \\
\text { ual }\end{array}$ & Clinic & $\begin{array}{l}\text { Caregiver } \\
\mathrm{s}\end{array}$ & $\begin{array}{l}\text { Cognitive } \\
\text { behavioral } \\
\text { therapy } \\
\text { sessions }\end{array}$ & NA & $\begin{array}{l}\text { 10-week period, with } \\
\text { each of the } 10 \\
\text { chapters taking } \\
\text { approximately } 20 \\
\text { minutes to complete }\end{array}$ & MM & $\begin{array}{l}\text { (Cogniti } \\
\text { ve) } \\
\text { social } \\
\text { learning } \\
\text { theory } \\
\end{array}$ \\
\hline $\begin{array}{l}\text { Dufresne } \\
\text { et al. } 2013\end{array}$ & France & Cohort & Ichthyosis & 6 and older & Group & $\begin{array}{l}\text { Reception } \\
\text { centre }\end{array}$ & \begin{tabular}{|l|} 
Physician \\
and \\
paramedic \\
team \\
member
\end{tabular} & \begin{tabular}{|l|} 
Two sessions \\
called 123 \\
Tem'peau \\
sessions And a \\
game with a set \\
of multiple- \\
choice \\
questions was \\
used.
\end{tabular} & $\begin{array}{l}\text { Children and } \\
\text { siblings: "What is } \\
\text { ichthyosis? Why do } \\
\text { I need the cream? } \\
\text { Why am I sick? Is it } \\
\text { normal to have } \\
\text { pain? What about } \\
\text { school and me? } \\
\text { What about the } \\
\text { hospital and me?" } \\
\text { Parents, children } \\
\text { and siblings >12 } \\
\text { years: "What is } \\
\text { ichthyosis? What } \\
\text { are the treatments? } \\
\text { What is genetics? } \\
\text { What is functional } \\
\text { management? } \\
\text { What are my social } \\
\text { rights?" The game } \\
\text { addressed various } \\
\text { topics: therapy, } \\
\text { genetics, care, } \\
\text { pain, rehabilitation } \\
\text { and social rights. } \\
\end{array}$ & $\begin{array}{l}\text { Two sessions of two } \\
\text { hours each }\end{array}$ & $\mathrm{MM}+\mathrm{RM}$ & NA \\
\hline $\begin{array}{l}\text { Eccleston } \\
\text { et al. } 2003\end{array}$ & $\begin{array}{l}\text { United } \\
\text { Kingdom }\end{array}$ & Cohort & $\begin{array}{l}\text { Chronic } \\
\text { pain }\end{array}$ & 14.3 & \begin{tabular}{|l|} 
Individ \\
ual \\
and \\
family- \\
center \\
ed
\end{tabular} & Clinic & \begin{tabular}{|l|} 
A \\
paediatric \\
rheumatol \\
ogist, \\
clinical \\
psychologi \\
st, \\
physiother \\
\end{tabular} & $\begin{array}{l}\text { Educational } \\
\text { sessions, and } \\
\text { cognitive } \\
\text { behavioral } \\
\text { therapy } \\
\text { sessions. }\end{array}$ & $\begin{array}{l}\text { Many sessions } \\
\text { required evening or } \\
\text { weekend written } \\
\text { and skills practice } \\
\text { homework. } \\
\text { Patients received } \\
\text { written information } \\
\text { about all aspects of }\end{array}$ & \begin{tabular}{|l|} 
Overall contact time \\
was 110 hours ( 60 \\
hours of physical and \\
occupational activity; \\
35 hours of cognitive \\
therapy, and 15 \\
hours education). \\
Each session lasted
\end{tabular} & $\mathrm{MM}$ and $\mathrm{EM}$ & $\begin{array}{l}\text { (Cogniti } \\
\text { ve) } \\
\text { social } \\
\text { learning } \\
\text { theory, } \\
\text { and } \\
\text { Cognitiv } \\
\text { e } \\
\end{array}$ \\
\hline
\end{tabular}




\begin{tabular}{|c|c|c|c|c|c|c|c|c|c|c|c|c|}
\hline & & & & & & & \begin{tabular}{|l} 
apist, \\
occupatio \\
nal \\
therapist, \\
and a \\
nurse \\
\end{tabular} & & $\begin{array}{l}\text { the programme } \\
\text { which built into a } \\
\text { patient manual. }\end{array}$ & $\begin{array}{l}50 \text { minutes. The day } \\
\text { was structured as a } \\
\text { school day from } 900 \\
\text { am to } 345 \mathrm{pm} .\end{array}$ & & $\begin{array}{l}\text { behavior } \\
\text { al theory }\end{array}$ \\
\hline $\begin{array}{l}\text { Franklin et } \\
\text { al. } 2006\end{array}$ & $\begin{array}{l}\text { United } \\
\text { Kingdom }\end{array}$ & RCT & Diabetes & $11-16$ & \begin{tabular}{|l} 
Individ \\
ualize \\
d
\end{tabular} & $\begin{array}{l}\text { Clinic, and } \\
\text { by phone }\end{array}$ & \begin{tabular}{|l} 
Diabetes \\
healthcare \\
team
\end{tabular} & $\begin{array}{l}\text { Telemedicine } \\
\text { system (text- } \\
\text { messages on } \\
\text { phone) }\end{array}$ & $\begin{array}{l}\text { Individual goal- } \\
\text { setting at clinic. } \\
\text { Automated delivery } \\
\text { of a series of } \\
\text { messaging, } \\
\text { including a weekly } \\
\text { reminder of the } \\
\text { goal set, and a } \\
\text { daily message } \\
\text { providing tips, } \\
\text { information or } \\
\text { reminders to } \\
\text { reinforce this goal } \\
\text { (by phone). }\end{array}$ & NA & MM & $\begin{array}{l}\text { (Cogniti } \\
\text { ve) } \\
\text { social } \\
\text { learning } \\
\text { theory }\end{array}$ \\
\hline $\begin{array}{l}\text { Fuchs et } \\
\text { al. } 2013\end{array}$ & $\begin{array}{l}\text { Netherlan } \\
\text { ds }\end{array}$ & Cohort & \begin{tabular}{|l|} 
Juvenile \\
idiopathic \\
Arthritis
\end{tabular} & $14-19$ & \begin{tabular}{|l} 
Individ \\
ual
\end{tabular} & NA & $\begin{array}{l}\text { Child } \\
\text { psychologi } \\
\text { st and } \\
\text { counselor/ } \\
\text { philosoph } \\
\text { er }\end{array}$ & $\begin{array}{l}\text { Narrative self- } \\
\text { reflections }\end{array}$ & $\begin{array}{l}\text { Phase 1: self- } \\
\text { investigation, about } \\
\text { important life } \\
\text { experiences; } \\
\text { Phase 2: process- } \\
\text { promoting, about } \\
\text { daily situations and } \\
\text { coping, Phase 3: } \\
\text { second self- } \\
\text { investigation, } \\
\text { consistencies and } \\
\text { changes in person } \\
\text { narratives; }\end{array}$ & $\begin{array}{l}\text { Phase } 1 \text { included } \\
\text { one SMC session. } \\
\text { Phase } 2 \text { consists of } \\
6 \text { weekly individual } \\
\text { sessions of about } 1 \mathrm{~h} \\
\text { each. Phase } 3 \\
\text { consists of } 3 \text { weekly } \\
\text { individual sessions of } \\
\text { about } 1 \mathrm{~h} \text { each. }\end{array}$ & $\mathrm{RM}+\mathrm{EM}$ & $\begin{array}{l}\text { Self- } \\
\text { confront } \\
\text { ation } \\
\text { method }\end{array}$ \\
\hline
\end{tabular}




\begin{tabular}{|c|c|c|c|c|c|c|c|c|c|c|c|c|}
\hline $\begin{array}{l}\text { Gerber et } \\
\text { al. } 2007\end{array}$ & $\begin{array}{l}\text { United } \\
\text { States of } \\
\text { America }\end{array}$ & Cohort & Diabetes & $22.3 \mathrm{yrs}$ & \begin{tabular}{|l} 
Individ \\
ualize \\
$\mathrm{d}$, but \\
also \\
online \\
discus \\
sion \\
with \\
peers \\
possibl \\
e
\end{tabular} & Online & $\begin{array}{l}\text { Psycholog } \\
\text { ist, patient } \\
\text { advocacy } \\
\text { expert and } \\
\text { social } \\
\text { worker }\end{array}$ & $\begin{array}{l}\text { Telemedicine } \\
\text { system (web- } \\
\text { based) }\end{array}$ & $\begin{array}{l}\text { Educational } \\
\text { module, and goal- } \\
\text { setting exercises } \\
\text { with individualized } \\
\text { feedback, role- } \\
\text { playing, group } \\
\text { discussion, } \\
\text { empowerment } \\
\text { activities, and } \\
\text { communication } \\
\text { skills training to } \\
\text { improve } \\
\text { interactions with } \\
\text { health } \\
\text { professionals. } \\
\text { There was a } \\
\text { discussion board } \\
\text { available, and } \\
\text { there were three } \\
\text { 'ask the experts } \\
\text { segments'. } \\
\end{array}$ & NA & MM & NA \\
\hline $\begin{array}{l}\text { Grey et al. } \\
2009\end{array}$ & $\begin{array}{l}\text { United } \\
\text { States of } \\
\text { America }\end{array}$ & RCT & Diabetes & $9.9 \mathrm{yrs}$ & $\begin{array}{l}\text { Group } \\
\text { sessio } \\
\text { ns }\end{array}$ & Clinic & \begin{tabular}{|l|} 
Mental \\
health \\
profession \\
al
\end{tabular} & $\begin{array}{l}\text { Educational } \\
\text { sessions }\end{array}$ & $\begin{array}{l}\text { Role play, } \\
\text { coaching, and } \\
\text { practice at home. }\end{array}$ & 6 weekly sessions & RM and EM & \begin{tabular}{|l} 
(Cogniti \\
ve) \\
social \\
learning \\
theory \\
\end{tabular} \\
\hline $\begin{array}{l}\text { Hackett et } \\
\text { al. } 2005\end{array}$ & $\begin{array}{l}\text { United } \\
\text { Kingdom }\end{array}$ & $\begin{array}{l}\text { Cross- } \\
\text { sectiona } \\
\text { I }\end{array}$ & $\begin{array}{l}\text { Juvenile } \\
\text { Idiopathic } \\
\text { Arthritis }\end{array}$ & $\begin{array}{l}\text { Median: } 14 \\
\text { yrs }\end{array}$ & Group & Camp & $\begin{array}{l}\text { Occupatio } \\
\text { nal } \\
\text { therapist, } \\
\text { Physiother } \\
\text { apist, } \\
\text { Nurse / } \\
\text { therapist, } \\
\text { assistant } \\
\end{array}$ & \begin{tabular}{|l} 
Camping \\
program
\end{tabular} & $\begin{array}{l}\text { Climbing, } \\
\text { canoeing, abseiling } \\
\text { and a trip to a } \\
\text { theme park. }\end{array}$ & 4 day annual event & $\mathrm{RM}$ & $\mathrm{NA}$ \\
\hline $\begin{array}{l}\text { Hampel et } \\
\text { al. } 2003\end{array}$ & Germany & Cohort & Astma & $11.6 \mathrm{yrs}$ & Group & $\begin{array}{l}\text { Clinic } \\
\text { (inpatient) }\end{array}$ & \begin{tabular}{|l|} 
Psycholog \\
ical, \\
education \\
al, and \\
medical \\
staff \\
\end{tabular} & $\begin{array}{l}\text { Family } \\
\text { sessions } \\
\text { (seperate for } \\
\text { parents and } \\
\text { children) }\end{array}$ & $\begin{array}{l}\text { Educational group } \\
\text { work }\end{array}$ & $\begin{array}{l}4 \text { weeks stay, } 101 \mathrm{~h}- \\
\text { long training } \\
\text { sessions. }\end{array}$ & MM and EM & $\begin{array}{l}\text { Stress } \\
\text { theory }\end{array}$ \\
\hline
\end{tabular}




\begin{tabular}{|c|c|c|c|c|c|c|c|c|c|c|c|c|}
\hline $\begin{array}{l}\text { Hanauer et } \\
\text { al. } 2009\end{array}$ & $\begin{array}{l}\text { United } \\
\text { States of } \\
\text { America }\end{array}$ & RCT & Diabetes & $17.9 \mathrm{yrs}$ & \begin{tabular}{|l} 
Individ \\
ualize \\
$d$
\end{tabular} & Online & NA & $\begin{array}{l}\text { Telemedicine } \\
\text { system (web- } \\
\text { based) }\end{array}$ & $\begin{array}{l}\text { BG diaries (blood } \\
\text { glucose check) and } \\
\text { two daily factoids } \\
\text { of which one was } \\
\text { related to diabetes } \\
\text { and one related to } \\
\text { unusual fun facts } \\
\text { or trivia. System } \\
\text { sends reminders to } \\
\text { check BG, and } \\
\text { gives (positive) } \\
\text { feedback. }\end{array}$ & NA & MM & $\mathrm{NA}$ \\
\hline $\begin{array}{l}\text { Hayutin et } \\
\text { al. } 2009\end{array}$ & $\begin{array}{l}\text { United } \\
\text { States of } \\
\text { America }\end{array}$ & Cohort & $\begin{array}{l}\text { Inflammator } \\
\text { y Bowel } \\
\text { Disease }\end{array}$ & 13-17 yrs & $\begin{array}{l}\text { Group } \\
\text { sessio } \\
\text { ns }\end{array}$ & $\mathrm{NA}$ & NA & \begin{tabular}{|l|} 
Family \\
sessions \\
(separate for \\
parents and \\
children, except \\
for relaxation \\
session and \\
conflict \\
resolution \\
communication \\
session)
\end{tabular} & $\begin{array}{l}\text { Review of written } \\
\text { homework, didactic } \\
\text { presentations, } \\
\text { discussion, } \\
\text { problem solving } \\
\text { and practice of the } \\
\text { new skill, plans for } \\
\text { application during } \\
\text { the week, and } \\
\text { assignment of } \\
\text { homework related } \\
\text { to the skills. }\end{array}$ & 10 sessions & MM & $\begin{array}{l}\text { Cognitiv } \\
\text { e } \\
\text { behavior } \\
\text { al theory }\end{array}$ \\
\hline $\begin{array}{l}\text { Hechler et } \\
\text { al. } 2010\end{array}$ & Germany & Cohort & $\begin{array}{l}\text { Chronic } \\
\text { pain }\end{array}$ & $14.0 \mathrm{yrs}$ & $\begin{array}{l}\text { Individ } \\
\text { ualize } \\
\text { d }\end{array}$ & $\begin{array}{l}\text { Clinic } \\
\text { (inpatient) }\end{array}$ & Therapists & $\begin{array}{l}\text { Skills training } \\
\text { sessions }\end{array}$ & $\begin{array}{l}\text { Interoceptive } \\
\text { exposure; bilateral } \\
\text { stimulation in the } \\
\text { form of tapping; } \\
\text { and cognitive } \\
\text { coping strategies to } \\
\text { reduce pain } \\
\text { intensity. }\end{array}$ & NA & MM & NA \\
\hline $\begin{array}{l}\text { Herbert et } \\
\text { al. } 2013\end{array}$ & $\begin{array}{l}\text { United } \\
\text { States of } \\
\text { America }\end{array}$ & $\begin{array}{l}\text { Qualitati } \\
\text { ve }\end{array}$ & \begin{tabular}{|l} 
Diabetes \\
(type 1)
\end{tabular} & $11-14$ & Group & Clinic & \begin{tabular}{|l|} 
Study \\
team \\
counselor \\
s, but not \\
mentioned \\
who these \\
were
\end{tabular} & $\begin{array}{l}\text { TeamWork. } \\
\text { Adolescent- } \\
\text { parent type 1 } \\
\text { diabetes (T1D) } \\
\text { program } \\
\text { developed to } \\
\text { prevent } \\
\text { deterioration in } \\
\text { diabetes care } \\
\text { among } \\
\text { adolescents }\end{array}$ & $\begin{array}{l}\text { Coping skills } \\
\text { session topics } \\
\text { included } \\
\text { communication } \\
\text { and diabetes } \\
\text { management, } \\
\text { problem solving to } \\
\text { improve } \\
\text { blood glucose } \\
\text { management, } \\
\text { healthy food }\end{array}$ & NA & MM & NA \\
\hline
\end{tabular}




\begin{tabular}{|c|c|c|c|c|c|c|c|c|c|c|c|c|}
\hline & & & & & & & & $\begin{array}{l}\text { with T1D. } \\
\text { Coping skills or } \\
\text { education } \\
\text { group with a } \\
\text { study team } \\
\text { counselor at } \\
\text { four } \\
\text { consecutive } \\
\text { regularly } \\
\text { scheduled } \\
\text { diabetes clinic } \\
\text { visits. }\end{array}$ & $\begin{array}{l}\text { choices and } \\
\text { avoiding } \\
\text { arguments, and } \\
\text { how attitudes affect } \\
\text { behaviors and how } \\
\text { these relate to } \\
\text { physical activity. } \\
\text { Each session } \\
\text { started with an } \\
\text { overview of the skill } \\
\text { and was followed } \\
\text { by a discussion } \\
\text { about what was } \\
\text { typical for the } \\
\text { family and how } \\
\text { they could use the } \\
\text { skill in daily life. }\end{array}$ & & & \\
\hline $\begin{array}{l}\text { Hilberink et } \\
\text { al. } 2013\end{array}$ & $\begin{array}{l}\text { Netherlan } \\
\text { ds }\end{array}$ & $\begin{array}{l}\text { Mixed } \\
\text { methods }\end{array}$ & $\begin{array}{l}\text { Cerebral } \\
\text { palsy, spina } \\
\text { bifida, } \\
\text { Neuromusc } \\
\text { ular disease }\end{array}$ & $19.9 \mathrm{yrs}$ & Group & \begin{tabular}{|l|} 
School, \\
and \\
rehabilitati \\
on clinics
\end{tabular} & $\begin{array}{l}\text { Pedagogu } \\
\text { es, } \\
\text { psychologi } \\
\text { sts, social } \\
\text { workers, a } \\
\text { sexologist, } \\
\text { and a } \\
\text { teacher }\end{array}$ & $\begin{array}{l}\text { Educational/su } \\
\text { pport sessions }\end{array}$ & $\begin{array}{l}\text { Homework } \\
\text { assignments }\end{array}$ & $\begin{array}{l}7 \text { sessions (90 min } \\
\text { each, scheduled } \\
\text { over a 12-week } \\
\text { period). }\end{array}$ & $\mathrm{RM}$ and $\mathrm{EM}$ & $\begin{array}{l}\begin{array}{l}\text { Flirt } \\
\text { model }\end{array} \\
\end{array}$ \\
\hline $\begin{array}{l}\text { Hojberg et } \\
\text { al. } 2010\end{array}$ & Denmark & Cohort & $\begin{array}{l}\text { Congenital } \\
\text { physical } \\
\text { disability }\end{array}$ & $18-25 \mathrm{yrs}$ & \begin{tabular}{|l|} 
Group \\
sessio \\
ns
\end{tabular} & \begin{tabular}{|l|} 
Rehabilitat \\
ion clinic \\
(and a trip \\
to \\
Lithuania)
\end{tabular} & $\begin{array}{l}\text { Occupatio } \\
\text { nal } \\
\text { therapist, } \\
\text { and a } \\
\text { socio- } \\
\text { education } \\
\text { al } \\
\text { assistant } \\
\text { (if } \\
\text { necessary } \\
\text { another } \\
\text { assistant } \\
\text { was hired) } \\
\end{array}$ & $\begin{array}{l}\text { Developmental } \\
\text { instructional } \\
\text { training course } \\
\text { (skills training } \\
\text { sessions) }\end{array}$ & NA & $\begin{array}{l}\text { The group met } 20 \\
\text { hours per week, } 4 \\
\text { days a week. } \\
\text { Approximately every } \\
\text { sixth week out of } \\
\text { house activities of } 2- \\
3 \text { days duration. In } \\
\text { addition: a 10-day } \\
\text { study trip to } \\
\text { Lithuania. }\end{array}$ & RM & NA \\
\hline $\begin{array}{l}\text { Huss et al. } \\
2003\end{array}$ & $\begin{array}{l}\text { United } \\
\text { States of } \\
\text { America }\end{array}$ & RCT & Asthma & $9.6 \mathrm{yrs}$ & \begin{tabular}{|l|} 
Individ \\
ual
\end{tabular} & Home & $\overline{N A}$ & CD-ROM & $\begin{array}{l}\text { Interactive game } \\
\text { including levels } \\
\text { and quizzes and } \\
\text { feedback from an } \\
\text { on-screen nurse. }\end{array}$ & NA & $\overline{\mathrm{MM}}$ & NA \\
\hline
\end{tabular}




\begin{tabular}{|c|c|c|c|c|c|c|c|c|c|c|c|c|}
\hline $\begin{array}{l}\text { Jan et al. } \\
2007\end{array}$ & | Taiwan & RCT & Asthma & | 10.5 yrs & $\begin{array}{l}\text { Individ } \\
\text { ual }\end{array}$ & $\mid \begin{array}{l}\text { Clinic } \\
\text { (outpatient } \\
\text { ) }\end{array}$ & NA & $\begin{array}{l}\text { Telemedicine } \\
\text { system } \\
\text { (Internet- } \\
\text { based) }\end{array}$ & \begin{tabular}{|l|} 
Educational \\
modules, electronic \\
diary, action plan, \\
and monitoring \\
system
\end{tabular} & NA & MM & NA \\
\hline $\begin{array}{l}\text { Jones et al. } \\
2010\end{array}$ & $\begin{array}{l}\text { United } \\
\text { States of } \\
\text { America }\end{array}$ & RCT & Cancer & $12-18$ yrs & $\begin{array}{l}\text { Individ } \\
\text { ual }\end{array}$ & Home & \begin{tabular}{|l|} 
Trained \\
healthcare \\
profession \\
als
\end{tabular} & CD-ROM & $\begin{array}{l}\text { Information videos, } \\
\text { text, stories, and a } \\
\text { game. }\end{array}$ & $\mathrm{NA}$ & MM and RM & $\overline{N A}$ \\
\hline $\begin{array}{l}\text { Joseph et } \\
\text { al. } 2007\end{array}$ & $\begin{array}{l}\text { United } \\
\text { States of } \\
\text { America }\end{array}$ & RCT & Asthma & 15.3 yrs & $\begin{array}{l}\text { Individ } \\
\text { ual }\end{array}$ & School & $\mathrm{NA}$ & $\begin{array}{l}\text { Telemedicine } \\
\text { system (web- } \\
\text { based) }\end{array}$ & \begin{tabular}{|l|} 
Theory-based \\
health messages \\
and information on \\
Asthma control. \\
Normative \\
(compared with \\
other students) and \\
ipsative (compared \\
with your last \\
session) feedback.
\end{tabular} & NA & MM & \begin{tabular}{|l} 
Transth \\
eoretical \\
, and \\
Health \\
belief \\
model
\end{tabular} \\
\hline $\begin{array}{l}\text { Kashikar- } \\
\text { Zuck et al. } \\
2012 ; 2013\end{array}$ & $\begin{array}{l}\text { United } \\
\text { States of } \\
\text { America }\end{array}$ & RCT & $\begin{array}{l}\text { Juvenile } \\
\text { Fibromyalgi } \\
\text { a }\end{array}$ & 15.0 yrs & $\begin{array}{l}\text { Individ } \\
\text { ual }\end{array}$ & Clinic & \begin{tabular}{l|} 
Therapists \\
with \\
postdoctor \\
al training \\
in \\
pediatric \\
psycholog \\
y
\end{tabular} & \begin{tabular}{|l|} 
Cognitive- \\
behavioral \\
therapy \\
sessions (in 3 \\
of the 8 parents \\
were also \\
present)
\end{tabular} & \begin{tabular}{|l|} 
Education and \\
skills training. \\
Instructions for \\
home practice \\
were also reviewed \\
with participants.
\end{tabular} & $\begin{array}{l}8 \text { weekly individual } \\
\text { sessions, and } 2 \\
\text { booster sessions. }\end{array}$ & MM & $\begin{array}{l}\text { Cognitiv } \\
\text { e } \\
\text { behavior } \\
\text { al theory }\end{array}$ \\
\hline $\begin{array}{l}\text { Kato et al. } \\
2008\end{array}$ & $\begin{array}{l}\text { United } \\
\text { States of } \\
\text { America }\end{array}$ & RCT & Cancer & $13-29$ yrs & $\begin{array}{l}\text { Individ } \\
\text { ual }\end{array}$ & $\mathrm{NA}$ & NA & $\begin{array}{l}\text { CD-ROM (PC- } \\
\text { game) }\end{array}$ & Game & NA & MM & $\begin{array}{l}\text { Self- } \\
\text { regulatio } \\
\mathrm{n} \text { theory, } \\
\text { and } \\
\text { (Cogniti } \\
\text { ve) } \\
\text { social } \\
\text { learning } \\
\text { theory }\end{array}$ \\
\hline $\begin{array}{l}\text { Koontz et } \\
\text { al. } 2004\end{array}$ & $\begin{array}{l}\text { United } \\
\text { States of } \\
\text { America }\end{array}$ & RCT & $\begin{array}{l}\text { Sickle cell } \\
\text { disease } \\
\text { (anemia) }\end{array}$ & $8-12$ yrs & $\begin{array}{l}\text { Group } \\
\text { sessio } \\
n\end{array}$ & School & Teachers & School program & Peer education & 1 hour & $\mathrm{MM}$ and $\mathrm{RM}$ & NA \\
\hline $\begin{array}{l}\text { Kouba et } \\
\text { al. } 2013\end{array}$ & $\begin{array}{l}\text { United } \\
\text { States of } \\
\text { America }\end{array}$ & Cohort & Asthma & 15.9 & $\begin{array}{l}\text { Group } \\
\text { and } \\
\text { individ }\end{array}$ & School & $\begin{array}{l}\text { Registere } \\
\text { d nurses, } \\
\text { dietitian }\end{array}$ & \begin{tabular}{|l|} 
The ICAN \\
program is thus \\
composed of
\end{tabular} & $\begin{array}{l}\text { Quest for the } \\
\text { Code, an } \\
\text { interactive, three- }\end{array}$ & $\begin{array}{l}\text { The ICAN } \\
\text { educational session } \\
\text { covered an 8-week }\end{array}$ & MM & $\begin{array}{l}\text { Orem's } \\
\text { Self- } \\
\text { Care }\end{array}$ \\
\hline
\end{tabular}




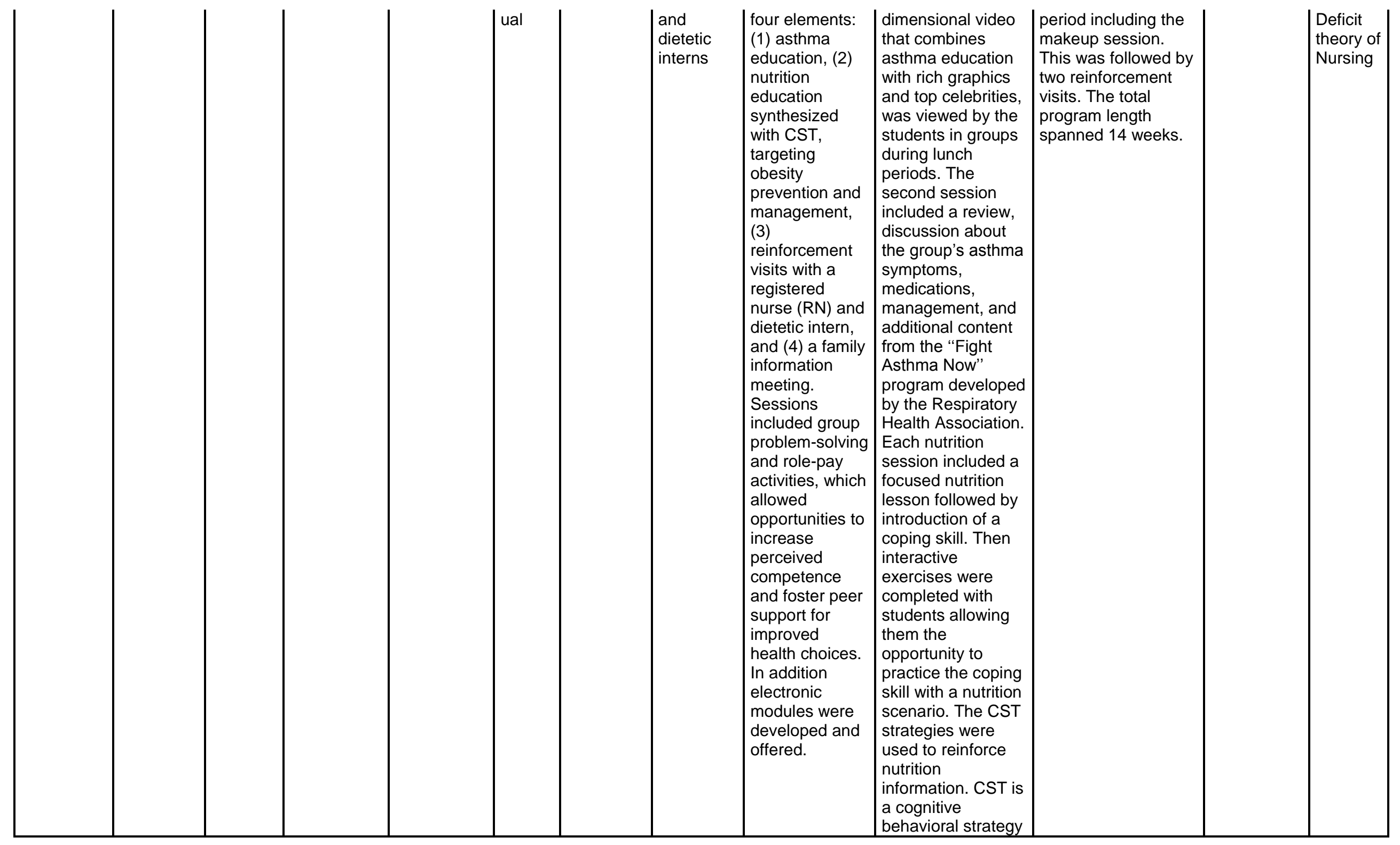




\begin{tabular}{|c|c|c|c|c|c|c|c|c|c|c|c|c|}
\hline & & & & & & & & & \begin{tabular}{|l|} 
that teaches \\
students personal \\
and social coping \\
skills to assist in \\
making health- \\
related decisions. \\
Electronic \\
modules: These \\
interactive modules \\
encouraged \\
students to seek \\
resources and \\
make decisions \\
related to the \\
target behaviors \\
using existing \\
Internet resources.
\end{tabular} & & & \\
\hline $\begin{array}{l}\text { Krishna et } \\
\text { al. } 2003\end{array}$ & \begin{tabular}{|l} 
United \\
States of \\
America
\end{tabular} & RCT & Asthma & 7-17 yrs old & \begin{tabular}{|l|} 
Individ \\
ual \\
(clinica \\
I staff \\
leaves \\
when \\
the \\
patient \\
is \\
workin \\
g on \\
IMPA \\
CT)
\end{tabular} & Clinic & \begin{tabular}{|l} 
Multidiscip \\
linary \\
team \\
involved in \\
determinin \\
g content \\
of the \\
program.
\end{tabular} & $\begin{array}{l}\text { Telemedicine } \\
\text { system } \\
\text { (interactive } \\
\text { multimedia } \\
\text { program) }\end{array}$ & \begin{tabular}{|l|} 
Animated lessons, \\
each averaging a \\
minute in length. \\
Each template was \\
designed to \\
illustrate concepts, \\
test \\
comprehension \\
and reinforce \\
learning, develop \\
decision-making \\
skills or improve a \\
child's ability to \\
communicate their \\
asthma. \\
\end{tabular} & During office visits & MM & NA \\
\hline $\begin{array}{l}\text { Kumar et } \\
\text { al. } 2004\end{array}$ & $\begin{array}{l}\text { United } \\
\text { States of } \\
\text { America }\end{array}$ & RCT & Diabetes & $13.6 \mathrm{yrs}$ & \begin{tabular}{|l|} 
Individ \\
ual
\end{tabular} & Online & NA & $\begin{array}{l}\text { Telemedicine } \\
\text { system } \\
\text { (personal } \\
\text { device) }\end{array}$ & Game with rewards & NA & MM & NA \\
\hline
\end{tabular}




\begin{tabular}{|c|c|c|c|c|c|c|c|c|c|c|c|c|}
\hline $\begin{array}{l}\text { Laffel et al. } \\
2003\end{array}$ & $\begin{array}{l}\text { United } \\
\text { States of } \\
\text { America }\end{array}$ & RCT & Diabetes & $12.1 \mathrm{yrs}$ & $\begin{array}{l}\text { Individ } \\
\text { ualize } \\
\text { d, } \\
\text { child } \\
\text { with } \\
\text { parent } \\
\text { (during } \\
\text { office } \\
\text { visits) }\end{array}$ & Clinic & $\begin{array}{l}\text { Research } \\
\text { assistant }\end{array}$ & $\begin{array}{l}\text { Family } \\
\text { sessions (for } \\
\text { child and } \\
\text { parent } \\
\text { together) }\end{array}$ & $\begin{array}{l}\text { Written materials, } \\
\text { discussion, making } \\
\text { a responsibility- } \\
\text { sharing plan }\end{array}$ & During office visits & $\mathrm{MM}$ & NA \\
\hline $\begin{array}{l}\text { Løding et } \\
\text { al. } 2008\end{array}$ & Norway & Cohort & Diabetes & $13-17$ yrs & $\begin{array}{l}\text { Group } \\
\text { sessio } \\
\text { ns }\end{array}$ & \begin{tabular}{l|} 
Clinic \\
(outpatient \\
)
\end{tabular} & $\begin{array}{l}\text { A team of } \\
\text { nurses, } \\
\text { medical } \\
\text { doctors, } \\
\text { and a } \\
\text { trained } \\
\text { social } \\
\text { worker }\end{array}$ & $\begin{array}{l}\text { Separate } \\
\text { support/educati } \\
\text { onal/skills } \\
\text { sessions for } \\
\text { adolescents } \\
\text { and parents }\end{array}$ & $\begin{array}{l}\text { Warm-up activity } \\
\text { such as } \\
\text { painting, } \\
\text { movement/exercise } \\
\text { s, or a round of } \\
\text { questions about } \\
\text { topics that were not } \\
\text { related to diabetes, } \\
\text { followed by group } \\
\text { discussion. }\end{array}$ & NA & $\begin{array}{l}\text { MM, RM } \\
\text { and EM }\end{array}$ & NA \\
\hline $\begin{array}{l}\text { MacDonald } \\
\& \\
\text { Greggans } \\
2010\end{array}$ & $\begin{array}{l}\text { United } \\
\text { Kingdom }\end{array}$ & $\begin{array}{l}\text { Qualitati } \\
\text { ve }\end{array}$ & \begin{tabular}{|l|} 
Cystic \\
Fibrosis
\end{tabular} & $8-18$ yrs & \begin{tabular}{|l|} 
Individ \\
ual
\end{tabular} & $\begin{array}{l}\text { Home/pub } \\
\text { lic } \\
\text { environme } \\
\text { nt }\end{array}$ & \begin{tabular}{|l|} 
Volunteer \\
s (after \\
following a \\
training \\
programm \\
e) \\
\end{tabular} & Peer-support & Mentorship & NA & EM & NA \\
\hline \begin{tabular}{|l} 
Martin et \\
al. 2009
\end{tabular} & $\begin{array}{l}\text { United } \\
\text { Kingdom }\end{array}$ & Cohort & Diabetes & $9-11$ yrs & $\begin{array}{l}\text { Group } \\
\text { sessio } \\
\text { ns }\end{array}$ & Clinic & $\begin{array}{l}\text { Pediatric } \\
\text { diabetes } \\
\text { nurse } \\
\text { specialist, } \\
\text { assistant } \\
\text { psychologi } \\
\text { st under } \\
\text { supervisio } \\
n \text { of a } \\
\text { consultant } \\
\text { (pediatric } \\
\text { clinical } \\
\text { psychologi } \\
\text { st). }\end{array}$ & $\begin{array}{l}\text { Educational } \\
\text { sessions }\end{array}$ & $\begin{array}{l}\text { Educational stories } \\
\text { about diabetes, } \\
\text { group discussions, } \\
\text { coloring/drawing } \\
\text { pictures, one-to- } \\
\text { one computer } \\
\text { session. }\end{array}$ & NA & MM and EM & $\begin{array}{l}\text { (Cogniti } \\
\text { ve) } \\
\text { social } \\
\text { learning } \\
\text { theory }\end{array}$ \\
\hline
\end{tabular}




\begin{tabular}{|c|c|c|c|c|c|c|c|c|c|c|c|c|}
\hline $\begin{array}{l}\text { Maurice- } \\
\text { Stam et al. } \\
2009\end{array}$ & $\begin{array}{l}\text { Netherlan } \\
\text { ds }\end{array}$ & Cohort & Cancer & 8-12 years & $\begin{array}{l}\text { Group } \\
\text { sessio } \\
\text { ns }\end{array}$ & $\begin{array}{l}\text { Clinic } \\
\text { (outpatient } \\
\text { ) }\end{array}$ & \begin{tabular}{|l} 
Dermatolo \\
gists or \\
pediatricia \\
ns, \\
psychologi \\
sts, and \\
dietitians \\
\end{tabular} & $\begin{array}{l}\text { Educational/skil } \\
\text { Is/support } \\
\text { sessions }\end{array}$ & $\begin{array}{l}\text { Modelling, } \\
\text { contingency } \\
\text { management, } \\
\text { exposure exercises } \\
\text { and cognitive } \\
\text { techniques. }\end{array}$ & NA & $\begin{array}{l}\text { MM, RM } \\
\text { and EM }\end{array}$ & $\begin{array}{l}\text { Cognitiv } \\
\text { e } \\
\text { behavior } \\
\text { al theory }\end{array}$ \\
\hline $\begin{array}{l}\text { McClellan } \\
\text { et al. } 2009\end{array}$ & $\begin{array}{l}\text { United } \\
\text { States of } \\
\text { America }\end{array}$ & $\begin{array}{l}\text { Cross- } \\
\text { sectiona } \\
1\end{array}$ & \begin{tabular}{|l|} 
Sickle Cell \\
Disease
\end{tabular} & $8-20$ yrs & $\begin{array}{l}\text { Group } \\
\text { sessio } \\
\mathrm{n} \text { and } \\
\text { individ } \\
\text { ual } \\
\text { device }\end{array}$ & $\begin{array}{l}\text { Clinic, and } \\
\text { by phone }\end{array}$ & $\mathrm{NA}$ & $\begin{array}{l}\text { Skills training } \\
\text { session, and } \\
\text { telemedicine } \\
\text { system } \\
\text { (personal } \\
\text { device) }\end{array}$ & $\begin{array}{l}\text { Daily pain diary } \\
\text { and coping skills } \\
\text { practice (through } \\
\text { audio files). }\end{array}$ & NA & MM & $\begin{array}{l}\text { Cognitiv } \\
\text { e } \\
\text { behavior } \\
\text { al theory }\end{array}$ \\
\hline $\begin{array}{l}\text { McDonagh } \\
\text { et al. } 2007\end{array}$ & $\begin{array}{l}\text { United } \\
\text { Kingdom }\end{array}$ & Cohort & $\begin{array}{l}\text { Juvenile } \\
\text { Idiopathic } \\
\text { Arthritis }\end{array}$ & 14.2 yrs & \begin{tabular}{|l|} 
Individ \\
ual
\end{tabular} & Clinic & $\begin{array}{l}\text { Project } \\
\text { coordinato } \\
\text { r from } \\
\text { clinic } \\
\text { assisted } \\
\text { by local } \\
\text { consultant } \\
\text { rheumatol } \\
\text { ogist }\end{array}$ & \begin{tabular}{|l} 
Individual \\
(transition) plan
\end{tabular} & $\begin{array}{l}\text { Age and } \\
\text { developmentally } \\
\text { appropriate } \\
\text { information } \\
\text { resources, and } \\
\text { goal-setting }\end{array}$ & NA & MM and RM & NA \\
\hline $\begin{array}{l}\text { Meade et } \\
\text { al. } 2003\end{array}$ & $\begin{array}{l}\text { United } \\
\text { States of } \\
\text { America }\end{array}$ & $\begin{array}{l}\text { Cross- } \\
\text { sectiona } \\
\text { I }\end{array}$ & $\begin{array}{l}\text { End-stage } \\
\text { renal } \\
\text { disease }\end{array}$ & $13.7 \mathrm{yrs}$ & $\begin{array}{l}\text { Group } \\
\text { sessio } \\
\text { ns }\end{array}$ & Clinic & $\begin{array}{l}\text { A nurse } \\
\text { from the } \\
\text { transplant } \\
\text { team, and } \\
\text { a } \\
\text { nephrologi } \\
\text { st. }\end{array}$ & $\begin{array}{l}\text { Educational/skil } \\
\text { Is/support } \\
\text { sessions }\end{array}$ & $\begin{array}{l}\text { Problem solving, } \\
\text { stress } \\
\text { management/relax } \\
\text { ation, talking with } \\
\text { other teens and/or } \\
\text { parents, } \\
\text { communication } \\
\text { role-plays, } \\
\text { questions and } \\
\text { answers with the } \\
\text { nephrologist, } \\
\text { medication } \\
\text { presentation by the } \\
\text { nurse. }\end{array}$ & 2 4-hour sessions & $\mathrm{MM}$ & $\mathrm{NA}$ \\
\hline $\begin{array}{l}\text { Merlijn et } \\
\text { al. } 2005\end{array}$ & $\begin{array}{l}\text { Netherlan } \\
\text { ds }\end{array}$ & Cohort & Pain & $14-18$ yrs & $\begin{array}{l}\text { Group } \\
\text { sessio } \\
\text { ns, } \\
\text { and } \\
\text { individ } \\
\text { ual } \\
\end{array}$ & Clinic & $\mathrm{NA}$ & $\begin{array}{l}\text { Educational } \\
\text { and skills } \\
\text { training } \\
\text { sessions (two } \\
\text { sessions were } \\
\text { for parents }\end{array}$ & $\begin{array}{l}\text { Training and } \\
\text { exercise book, } \\
\text { peers, written } \\
\text { material, exercises } \\
\text { and homework } \\
\text { assignments. }\end{array}$ & $\mathrm{NA}$ & $\begin{array}{l}\text { MM, RM } \\
\text { and EM }\end{array}$ & $\begin{array}{l}\text { (Cogniti } \\
\text { ve) } \\
\text { social } \\
\text { learning } \\
\text { theory }\end{array}$ \\
\hline
\end{tabular}




\begin{tabular}{|c|c|c|c|c|c|c|c|c|c|c|c|c|}
\hline & & & & & \begin{tabular}{|l} 
teleph \\
one \\
contac \\
ts
\end{tabular} & & & $\begin{array}{l}\text { only: one at the } \\
\text { beginning and } \\
\text { one at the end). } \\
\text { The others } \\
\text { were for } \\
\text { adolescents } \\
\text { only. }\end{array}$ & & & & \\
\hline $\begin{array}{l}\text { Nansel et } \\
\text { al. } 2007\end{array}$ & $\begin{array}{l}\text { United } \\
\text { States of } \\
\text { America }\end{array}$ & Cohort & Diabetes & $11-16 \mathrm{yrs}$ & \begin{tabular}{|l|} 
Individ \\
ualize \\
$d$
\end{tabular} & $\begin{array}{l}\text { Home or } \\
\text { public } \\
\text { environme } \\
\text { nt }\end{array}$ & $\begin{array}{l}\text { Trained } \\
\text { non- } \\
\text { profession } \\
\text { als } \\
\text { (bachelor } \\
\text { degree } \\
\text { and/or } \\
\text { graduate } \\
\text { students } \\
\text { in health } \\
\text { related } \\
\text { fields) }\end{array}$ & $\begin{array}{l}\text { Skills training } \\
\text { sessions with } \\
\text { motivational } \\
\text { interviewing } \\
\text { incorporated, } \\
\text { supplemented } \\
\text { with telephone } \\
\text { calls. }\end{array}$ & $\begin{array}{l}\text { Reviewing self- } \\
\text { monitoring records, } \\
\text { goal-setting, going } \\
\text { through the steps } \\
\text { of behavior } \\
\text { change, } \\
\text { brainstorming } \\
\text { about possible } \\
\text { solutions of } \\
\text { difficulties } \\
\text { encountered } \\
\text { (problem-solving). } \\
\text { The personal } \\
\text { trainers provided } \\
\text { suggestions, } \\
\text { encouragement, } \\
\text { and positive } \\
\text { feedback. }\end{array}$ & 6 sessions & $\overline{M M}$ & NA \\
\hline $\begin{array}{l}\text { Newcombe } \\
\text { et al. } 2012\end{array}$ & Australia & RCT & $\begin{array}{l}\text { Chronic } \\
\text { respiratory } \\
\text { condition }\end{array}$ & $13.4 \mathrm{yrs}$ & \begin{tabular}{|l|} 
Individ \\
ualize \\
d, but \\
also \\
online \\
conver \\
sation \\
with \\
peers
\end{tabular} & Online & $\mathrm{NA}$ & $\begin{array}{l}\text { Telemedicine } \\
\text { system } \\
\text { (educational } \\
\text { website) }\end{array}$ & $\begin{array}{l}\text { Information on } \\
\text { web-site, daily } \\
\text { diary, } \\
\text { assignments/home } \\
\text { work and peer } \\
\text { contact. }\end{array}$ & NA & $\mathrm{MM}$ & NA \\
\hline $\begin{array}{l}\text { Newton \& } \\
\text { Ashley } \\
2013\end{array}$ & $\begin{array}{l}\text { United } \\
\text { States of } \\
\text { America }\end{array}$ & $\mathrm{RCT}$ & $\begin{array}{l}\text { Diabetes } \\
\text { (type 1) }\end{array}$ & 13-18 & $\begin{array}{l}\text { Individ } \\
\text { ual, } \\
\text { but } \\
\text { online } \\
\text { contac } \\
\text { t with } \\
\text { peers }\end{array}$ & Online & $\begin{array}{l}\text { Moderator } \\
\mathrm{s} \text {, but not } \\
\text { mentioned } \\
\text { who these } \\
\text { were }\end{array}$ & \begin{tabular}{|l|} 
Telemedicine \\
system: \\
interactive web- \\
based \\
intervention \\
with problem \\
solving through \\
discussion in \\
forums, chat \\
\end{tabular} & $\begin{array}{l}\text { Three types of } \\
\text { asynchronous } \\
\text { discussions were } \\
\text { held in the forums: } \\
\text { 1) General } \\
\text { discussion on the } \\
\text { weekly topic. 2) } \\
\text { Diabetes-related } \\
\text { scenarios }\end{array}$ & $\begin{array}{l}\text { 7-week, weekly } \\
\text { topics }\end{array}$ & $\begin{array}{l}\mathrm{MM}+\mathrm{RM}+\mathrm{E} \\
\mathrm{M}\end{array}$ & $\begin{array}{l}\text { Bandura } \\
\text { 's Self- } \\
\text { Efficacy } \\
\text { Theory }\end{array}$ \\
\hline
\end{tabular}




\begin{tabular}{|c|c|c|c|c|c|c|c|c|c|c|c|c|}
\hline & & & & & & & & $\begin{array}{l}\text { rooms and } \\
\text { blogs }\end{array}$ & \begin{tabular}{l|} 
discussing \\
psychosocial \\
diabetes-related \\
issues. 3) Open \\
discussion where \\
participants could \\
post their own \\
problems to the \\
group. Weekly \\
topics were: \\
Frustrations with \\
diabetes, Benefits \\
of good control, \\
Family, Friends, \\
Body image, \\
exercise and diet, \\
Community, School \\
and sports, Worries \\
about diabetes. \\
\end{tabular} & & & \\
\hline $\begin{array}{l}\text { Ng et al. } \\
2008\end{array}$ & China & RCT & Asthma & $9.2 \mathrm{yrs}$ & $\begin{array}{l}\text { Group } \\
\text { sessio } \\
\text { ns }\end{array}$ & Clinic & NA & $\begin{array}{l}\text { Educational/su } \\
\text { pport sessions }\end{array}$ & \begin{tabular}{|l} 
Joint activity (to \\
talk about take- \\
home tasks from \\
previous meeting), \\
parallel groups \\
(children and \\
parents work \\
separately on a \\
common theme), \\
joint activity \\
(discussion). \\
\end{tabular} & $\begin{array}{l}\text { educational } \\
\text { sessions, and } 6 \\
\text { support sessions. }\end{array}$ & $\begin{array}{l}\text { MM, RM } \\
\text { and EM }\end{array}$ & NA \\
\hline $\begin{array}{l}\text { O'Mahar et } \\
\text { al. } 2010 \\
\text { Holbein et } \\
\text { al. } 2013 \\
\end{array}$ & $\begin{array}{l}\text { United } \\
\text { States of } \\
\text { America }\end{array}$ & Cohort & Spina bifida & $16.6 \mathrm{yrs}$ & $\begin{array}{l}\text { Group } \\
\text { and } \\
\text { individ } \\
\text { ual }\end{array}$ & Camp & \begin{tabular}{l|} 
Counselor \\
s, but not \\
mentioned \\
who these \\
are.
\end{tabular} & $\begin{array}{l}\text { Camping } \\
\text { program with } \\
\text { support } \\
\text { sessions }\end{array}$ & NA & $\begin{array}{l}\text { 112-hour group } \\
\text { sessions }\end{array}$ & RM and EM & NA \\
\hline $\begin{array}{l}\text { Palermo et } \\
\text { al. } 2009 \\
\text { Fales et al. } \\
2014\end{array}$ & $\begin{array}{l}\text { United } \\
\text { States of } \\
\text { America }\end{array}$ & RCT & \begin{tabular}{|l} 
Chronic \\
pain
\end{tabular} & $14.8 \mathrm{yrs}$ & $\begin{array}{l}\text { Individ } \\
\text { ualize } \\
\text { d }\end{array}$ & Online & $\begin{array}{l}\text { Online } \\
\text { therapist: } \\
\text { a } \\
\text { psycholog } \\
\text { y } \\
\text { postdoctor } \\
\text { al fellow } \\
\text { who had }\end{array}$ & $\begin{array}{l}\text { Telemedicine } \\
\text { system (web- } \\
\text { based } \\
\text { program). }\end{array}$ & $\begin{array}{l}\text { Treatment modules } \\
\text { with video files and } \\
\text { audio files, and } \\
\text { daily diary. Also } \\
\text { queries } \\
\text { (assignments). }\end{array}$ & NA & MM & $\begin{array}{l}\text { (Cogniti } \\
\text { ve) } \\
\text { social } \\
\text { learning } \\
\text { theory, } \\
\text { and } \\
\text { Cognitiv } \\
\text { e } \\
\end{array}$ \\
\hline
\end{tabular}




\begin{tabular}{|c|c|c|c|c|c|c|c|c|c|c|c|c|}
\hline & & & & & & & $\begin{array}{l}\text { one year } \\
\text { of specific } \\
\text { experienc } \\
\text { e in } \\
\text { delivery of } \\
\text { face-to- } \\
\text { face CBT }\end{array}$ & & & & & $\begin{array}{l}\text { behavior } \\
\text { al theory }\end{array}$ \\
\hline \begin{tabular}{|l|} 
Payne et \\
al. 2013
\end{tabular} & \begin{tabular}{|l|} 
United \\
States of \\
America
\end{tabular} & $\begin{array}{l}\text { Case } \\
\text { study }\end{array}$ & \begin{tabular}{|l} 
End-stage \\
renal \\
disease
\end{tabular} & $14-16$ & $\begin{array}{l}\text { Individ } \\
\text { ualize } \\
\text { d }\end{array}$ & Clinic & NA & $\begin{array}{l}\text { Six modules: } \\
\text { four individual } \\
\text { and two joint } \\
\text { (with parents). } \\
\text { A quiz was } \\
\text { given after } \\
\text { each sesion to } \\
\text { assess } \\
\text { knowledge of } \\
\text { skills before } \\
\text { progressing to } \\
\text { the next } \\
\text { module. }\end{array}$ & \begin{tabular}{|l} 
Sessions were \\
designed to identify \\
and address \\
knowledge, \\
behavioral, and \\
cognitive barriers \\
to medication \\
adherence. \\
Session $1:$ \\
knowledge and \\
education about \\
regimen, 2) sharing \\
regimen \\
responsibilities \\
(joint session), 3) \\
review of problem- \\
solving skills and \\
solutions (joint \\
session), 4) role of \\
cognitions as \\
adherence barriers, \\
5 ) emotional \\
regulation and \\
coping skills to \\
overcome barriers \\
to adherence, 6) \\
review of skills \\
learned throughout \\
intervention.
\end{tabular} & $\begin{array}{l}\text { The intervention was } \\
\text { completed in a } \\
\text { minimum of } 6 \text { weeks. } \\
\text { Including data } \\
\text { collection, sessions } \\
\text { lasted } 60 \text { to } 90 \\
\text { minutes. }\end{array}$ & \begin{tabular}{|l|}
$M M$ \\
\end{tabular} & \begin{tabular}{|l|} 
Health \\
Belief \\
model
\end{tabular} \\
\hline
\end{tabular}




\begin{tabular}{|c|c|c|c|c|c|c|c|c|c|c|c|c|}
\hline $\begin{array}{l}\text { Pulgaron et } \\
\text { al. } 2010\end{array}$ & $\begin{array}{l}\text { United } \\
\text { States of } \\
\text { America }\end{array}$ & RCT & Asthma & $10.4 \mathrm{yrs}$ & $\begin{array}{l}\text { Group } \\
\text { sessio } \\
\text { ns }\end{array}$ & Camp & \begin{tabular}{|l} 
Interventio \\
nists were \\
clinical \\
psycholog \\
y graduate \\
students, \\
trained \\
and \\
supervise \\
d by two \\
pediatric \\
psychologi \\
sts and an \\
advanced \\
graduate \\
student; \\
interventio \\
nists were \\
not camp \\
counselor \\
s.
\end{tabular} & $\begin{array}{l}\text { Camping } \\
\text { program with } \\
\text { skills training } \\
\text { sessions }\end{array}$ & \begin{tabular}{|l} 
Group discussion, \\
modeling of how to \\
apply the PAC-T, \\
and role plays. \\
Participants \\
received personal \\
manuals with blank \\
fill-in sheets to list \\
potential solutions \\
to each problem.
\end{tabular} & NA & MM & NA \\
\hline $\begin{array}{l}\text { Raghavend } \\
\text { ra et al. } \\
2013\end{array}$ & Australia & $\begin{array}{l}\text { Mixed } \\
\text { methods }\end{array}$ & $\begin{array}{l}\mathrm{CP}, \\
\text { physical } \\
\text { disability or } \\
\text { acquired } \\
\text { brain injury }\end{array}$ & $10-18$ & \begin{tabular}{|l|} 
Individ \\
ualize \\
d
\end{tabular} & Home & \begin{tabular}{|l} 
Speech \\
pathologis \\
$\mathrm{t}$ and \\
research \\
assistants
\end{tabular} & $\begin{array}{l}\text { Educational } \\
\text { and skills } \\
\text { training } \\
\text { sessions }\end{array}$ & \begin{tabular}{|l|} 
Focused on: \\
identifying and \\
evaluating the \\
family's current \\
computer and \\
Internet access; \\
teaching the youth \\
and family about \\
cyber safety \\
including the use of \\
filtering and privacy \\
settings, the \\
development of \\
house rules for \\
expected online \\
behaviour, and \\
explanations/ \\
discussion of age- \\
appropriate social \\
media; providing \\
appropriate \\
software and \\
\end{tabular} & NA & RM & $\mathrm{NA}$ \\
\hline
\end{tabular}




\begin{tabular}{|c|c|c|c|c|c|c|c|c|c|c|c|c|}
\hline & & & & & & & & & $\begin{array}{l}\text { equipment based } \\
\text { on the goals; } \\
\text { providing training } \\
\text { materials including } \\
\text { visual supports or } \\
\text { instructions as well } \\
\text { as hands on } \\
\text { training and } \\
\text { practice to use the } \\
\text { software, } \\
\text { equipment or } \\
\text { Internet; providing } \\
\text { interface solutions, } \\
\text { such as speech } \\
\text { recognition } \\
\text { software for text } \\
\text { entry, word- } \\
\text { prediction software } \\
\text { or screen reading } \\
\text { software. Training } \\
\text { was framed to } \\
\text { ensure youth } \\
\text { accessed the } \\
\text { identified web sites } \\
\text { to engage in social } \\
\text { networking with } \\
\text { their peers, friends } \\
\text { and families. } \\
\end{array}$ & & & \\
\hline $\begin{array}{l}\text { Rami et al. } \\
2006\end{array}$ & Austria & RCT & Diabetes & \begin{tabular}{|c|}
$10-19 \mathrm{yrs}$ \\
\end{tabular} & \begin{tabular}{|l} 
Individ \\
ualize \\
d
\end{tabular} & $\begin{array}{l}\text { Online/Ph } \\
\text { one }\end{array}$ & NA & $\begin{array}{l}\text { Telemedicine } \\
\text { system (on } \\
\text { phone) }\end{array}$ & $\begin{array}{l}\text { Monitoring through } \\
\text { daily diaries. }\end{array}$ & NA & $\mathrm{MM}$ & NA \\
\hline $\begin{array}{l}\text { Rhee et al. } \\
2011\end{array}$ & \begin{tabular}{|l} 
United \\
States of \\
America
\end{tabular} & RCT & Asthma & $14.6 \mathrm{yrs}$ & $\begin{array}{l}\text { Group } \\
\text { sessio } \\
\text { ns }\end{array}$ & Camp & \begin{tabular}{|l|} 
Peer \\
leaders \\
selected \\
by school \\
teachers $n$ \\
urses or \\
clinicians
\end{tabular} & $\begin{array}{l}\text { Camping } \\
\text { program }\end{array}$ & \begin{tabular}{|l|} 
Peer leaders led \\
group activities that \\
involved \\
discussion, \\
strategic thinking, \\
knowledge-testing \\
games, and role \\
playing.
\end{tabular} & $\begin{array}{l}\text { Each session lasted } \\
\text { approximately } 45-60 \\
\text { minutes. }\end{array}$ & MM and RM & NA \\
\hline
\end{tabular}




\begin{tabular}{|c|c|c|c|c|c|c|c|c|c|c|c|c|}
\hline $\begin{array}{l}\text { Rhee et al. } \\
2012\end{array}$ & $\begin{array}{l}\text { United } \\
\text { States of } \\
\text { America }\end{array}$ & RCT & Asthma & $17.6 \mathrm{yrs}$ & $\begin{array}{l}\text { Trainin } \\
\mathrm{g} \\
\text { sessio } \\
\mathrm{ns}\end{array}$ & Camp & \begin{tabular}{|l|} 
Peer \\
leaders \\
selected \\
by school \\
teachers/n \\
urses or \\
clinicians
\end{tabular} & $\begin{array}{l}\text { Camping } \\
\text { program }\end{array}$ & \begin{tabular}{|l|} 
Disease-specific \\
activities (sessions)
\end{tabular} & NA & NA & NA \\
\hline $\begin{array}{l}\text { Sattoe et } \\
\text { al. } 2013\end{array}$ & $\begin{array}{l}\text { Netherlan } \\
\text { ds }\end{array}$ & \begin{tabular}{|l|} 
Mixed \\
methods
\end{tabular} & \begin{tabular}{|l} 
End-stage \\
renal \\
disease
\end{tabular} & $16-25$ & Group & Camp & \begin{tabular}{|l|} 
Pediatric \\
nephrolog \\
y health \\
care \\
profession \\
als
\end{tabular} & $\begin{array}{l}\text { Camping } \\
\text { program: with } \\
\text { different } \\
\text { elements: } \\
\text { workshop } \\
\text { present } \\
\text { yourself, movie } \\
\text { making } \\
\text { workshop, } \\
\text { dancing } \\
\text { workshop, } \\
\text { sports, cooking } \\
\text { teams, free } \\
\text { time, theater } \\
\text { performance by } \\
\text { professional } \\
\text { artists, art } \\
\text { workshop, } \\
\text { drumming } \\
\text { workshop, } \\
\text { acting } \\
\text { workshop. Also: } \\
\text { buddy- } \\
\text { attendant } \\
\text { concept (peer- } \\
\text { to-peer } \\
\text { support). }\end{array}$ & \begin{tabular}{|l|} 
Aimed at \\
independent living \\
with ESRD and \\
developing self- \\
management skills, \\
but no focus on \\
disease-specific \\
issues; about \\
transition to \\
adulthood in \\
general, i.e. aimed \\
at general \\
competencies like \\
self-confidence, \\
self-efficacy etc.
\end{tabular} & Five days & RM+EM & NA \\
\hline $\begin{array}{l}\text { Shames et } \\
\text { al. } 2004\end{array}$ & $\begin{array}{l}\text { United } \\
\text { States of } \\
\text { America }\end{array}$ & RCT & Asthma & $8.0 \mathrm{yrs}$ & $\begin{array}{l}\text { Individ } \\
\text { ualize } \\
\text { d }\end{array}$ & $\begin{array}{l}\text { Clinic, and } \\
\text { home } \\
\text { environme } \\
\text { nt }\end{array}$ & \begin{tabular}{|l|} 
Case \\
manager, \\
allergist / \\
immunolo \\
gist, and \\
pediatric \\
nurses
\end{tabular} & $\begin{array}{l}\text { Educational } \\
\text { and skills } \\
\text { training } \\
\text { sessions }\end{array}$ & $\begin{array}{l}\text { Informational } \\
\text { books, phone calls } \\
\text { by interventionists, } \\
\text { video game, } \\
\text { asthma } \\
\text { management plan }\end{array}$ & NA & MM & NA \\
\hline
\end{tabular}




\begin{tabular}{|c|c|c|c|c|c|c|c|c|c|c|c|c|}
\hline $\begin{array}{l}\text { Smith } \\
\text { Fawzi et al. } \\
2012\end{array}$ & Haiti & $\begin{array}{l}\text { Mixed } \\
\text { methods }\end{array}$ & HIV & $10-17$ yrs & $\begin{array}{l}\text { Group } \\
\text { sessio } \\
\text { ns }\end{array}$ & Clinic & $\begin{array}{l}\text { Social } \\
\text { workers }\end{array}$ & $\begin{array}{l}\text { Family } \\
\text { sessions (child- } \\
\text { parent pairs) }\end{array}$ & $\begin{array}{l}\text { Sharing } \\
\text { experiences }\end{array}$ & $\begin{array}{l}\text { The sessions were } \\
\text { implemented over a } \\
\text { one year period (held } \\
\text { bi-monthly). }\end{array}$ & $\begin{array}{l}\text { MM, RM } \\
\text { and EM }\end{array}$ & $\begin{array}{l}\text { (Cogniti } \\
\text { ve) } \\
\text { social } \\
\text { learning } \\
\text { theory }\end{array}$ \\
\hline $\begin{array}{l}\text { Staab et al. } \\
2006\end{array}$ & Germany & RCT & \begin{tabular}{|l} 
Atopic \\
dermatitis \\
(Eczemia)
\end{tabular} & 8-18 yrs & $\begin{array}{l}\text { Group } \\
\text { sessio } \\
\text { ns }\end{array}$ & Clinic & $\begin{array}{l}\text { Dermatolo } \\
\text { gists, } \\
\text { pediatricia } \\
\text { ns, } \\
\text { psychologi } \\
\text { sts, and } \\
\text { dieticians } \\
\end{array}$ & $\begin{array}{l}\text { Educational } \\
\text { sessions and } \\
\text { skills training }\end{array}$ & $\begin{array}{l}\text { Sharing } \\
\text { experiences, } \\
\text { practicing skills }\end{array}$ & $\mathrm{NA}$ & MM and EM & $\mathrm{NA}$ \\
\hline $\begin{array}{l}\text { Stinson et } \\
\text { al. } 2010\end{array}$ & Canada & RCT & $\begin{array}{l}\text { Juvenile } \\
\text { Idiopathic } \\
\text { Arthritis }\end{array}$ & 15.6 yrs & $\begin{array}{l}\text { Individ } \\
\text { ualize } \\
d, \text { but } \\
\text { contac } \\
\text { t with } \\
\text { peers } \\
\text { possibl } \\
\text { e }\end{array}$ & Online & $\begin{array}{l}\text { Trained } \\
\text { coach: } \\
\text { non } \\
\text { healthcare } \\
\text { profession } \\
\text { al with an } \\
\text { undergrad } \\
\text { uate } \\
\text { degree in } \\
\text { psycholog } \\
\text { y }\end{array}$ & $\begin{array}{l}\text { Telemedicine } \\
\text { system (web- } \\
\text { based) }\end{array}$ & $\begin{array}{l}\text { Goal-setting } \\
\text { (diary), homework, } \\
\text { knowledge } \\
\text { quizzes, discussion } \\
\text { board, feedback } \\
\text { from coach }\end{array}$ & NA & $\begin{array}{l}\text { MM, RM } \\
\text { and EM }\end{array}$ & $\mathrm{NA}$ \\
\hline $\begin{array}{l}\text { Stulemeijer } \\
\text { et al. } 2005\end{array}$ & $\begin{array}{l}\text { Netherlan } \\
\text { ds }\end{array}$ & $\mathrm{RCT}$ & \begin{tabular}{|l|} 
Chronic \\
Fatigue \\
Syndrome
\end{tabular} & 15.5 yrs & $\begin{array}{l}\text { Individ } \\
\text { ualize } \\
d\end{array}$ & Clinic & $\begin{array}{l}\text { Child } \\
\text { therapists } \\
\text { who were } \\
\text { trained } \\
\text { and } \\
\text { supervise } \\
d \text { by an } \\
\text { experienc } \\
\text { ed } \\
\text { cognitive } \\
\text { behavioral } \\
\text { therapist }\end{array}$ & $\begin{array}{l}\text { Cognitive- } \\
\text { behavioral } \\
\text { therapy } \\
\text { sessions }\end{array}$ & NA & 10 sessions & $\begin{array}{l}\text { MM, RM } \\
\text { and EM }\end{array}$ & $\begin{array}{l}\text { Cognitiv } \\
\text { e } \\
\text { behavior } \\
\text { al theory }\end{array}$ \\
\hline $\begin{array}{l}\text { Ten Hoedt } \\
\text { et al. } 2011\end{array}$ & $\begin{array}{l}\text { Netherlan } \\
\text { ds }\end{array}$ & RCT & $\begin{array}{l}\text { Phenylketon } \\
\text { uria }\end{array}$ & 15 yrs & $\begin{array}{l}\text { Individ } \\
\text { ualize } \\
\text { d }\end{array}$ & Online & Dietician & $\begin{array}{l}\text { Telemedicine } \\
\text { system } \\
\text { (secured } \\
\text { website) }\end{array}$ & $\begin{array}{l}\text { Monitoring through } \\
\text { daily diaries }\end{array}$ & NA & MM & NA \\
\hline
\end{tabular}




\begin{tabular}{|c|c|c|c|c|c|c|c|c|c|c|c|c|}
\hline $\mid \begin{array}{l}\text { Torok et al. } \\
2006^{65}\end{array}$ & | Hungary & Cohort & \begin{tabular}{|l} 
Diabetes, \\
oncologie
\end{tabular} & $\begin{array}{l}\text { Oncologie } \\
15.58 \text { yrs; } \\
\text { Diabetes } \\
14.90 \text { yrs }\end{array}$ & Group & Camp & NA & $\begin{array}{l}\text { Camping } \\
\text { program }\end{array}$ & $\begin{array}{l}\text { Disease-specific } \\
\text { activities and } \\
\text { reinforcement of } \\
\text { positive thinking. }\end{array}$ & $\begin{array}{l}2 \text { separate 8-day } \\
\text { sessions }\end{array}$ & NA & NA \\
\hline \begin{tabular}{|l|} 
Velsor- \\
Friedrich et \\
al. 2005
\end{tabular} & \begin{tabular}{|l} 
United \\
States of \\
America
\end{tabular} & RCT & Asthma & $10.1 \mathrm{yrs}$ & \begin{tabular}{|l} 
Group \\
sessio \\
ns, \\
and \\
invidid \\
ualize \\
$d$ \\
nurse \\
visit \\
\end{tabular} & School & $\begin{array}{l}\text { Nurse } \\
\text { practitione } \\
r\end{array}$ & $\begin{array}{l}\text { Educational } \\
\text { sessions }\end{array}$ & $\begin{array}{l}\text { Interactive teaching } \\
\text { approach utilizing } \\
\text { group discussion, } \\
\text { stories, games, } \\
\text { and role-play. }\end{array}$ & Six weekly sessions & MM and RM & $\begin{array}{l}\text { Self- } \\
\text { care } \\
\text { theory }\end{array}$ \\
\hline \begin{tabular}{|l|} 
Verhoef et \\
al. 2014
\end{tabular} & $\begin{array}{l}\text { Netherlan } \\
\text { ds }\end{array}$ & Cohort & $\begin{array}{l}\text { Physical } \\
\text { disability }\end{array}$ & $16-25$ & $\begin{array}{l}\text { Group } \\
\text { and } \\
\text { individ } \\
\text { ual }\end{array}$ & $\begin{array}{l}\text { Clinic } \\
\text { (outpatient } \\
\text { ) }\end{array}$ & \begin{tabular}{|l|} 
Occupatio \\
nal \\
therapist, \\
psychologi \\
st, \\
jobcoach, \\
social \\
worker
\end{tabular} & $\begin{array}{l}\text { Educational } \\
\text { and skills } \\
\text { training } \\
\text { sessions }\end{array}$ & $\begin{array}{l}\text { Group sessions } \\
\text { provided } \\
\text { information and } \\
\text { discussion about } \\
\text { work-related topics } \\
\text { and aimed to } \\
\text { increase insight } \\
\text { into personal } \\
\text { (dis)abilities, } \\
\text { addressing work } \\
\text { objectives, coping } \\
\text { strategies } \\
\text { (dis)abilities, } \\
\text { addressing work } \\
\text { objectives, coping } \\
\text { strategies, } \\
\text { occupational } \\
\text { balance, finding a } \\
\text { (suitable) job, how } \\
\text { to present oneself } \\
\text { at a job interview, } \\
\text { and employment } \\
\text { regulations and } \\
\text { social security. In } \\
\text { addition, group } \\
\text { sessions offered } \\
\text { opportunities to } \\
\text { develop } \\
\text { communication and }\end{array}$ & \begin{tabular}{|l} 
Group support \\
programme \\
consisting of six 2- \\
hour sessions over 8 \\
weeks.
\end{tabular} & RM and EM & $\begin{array}{l}\text { Model of } \\
\text { human } \\
\text { occupati } \\
\text { on } \\
\text { (MOHO) }\end{array}$ \\
\hline
\end{tabular}




\begin{tabular}{|c|c|c|c|c|c|c|c|c|c|c|c|c|}
\hline & & & & & & & & & $\begin{array}{l}\text { interaction skills, to } \\
\text { share experiences, } \\
\text { and to increase } \\
\text { group members' } \\
\text { self-efficacy. } \\
\text { Homework } \\
\text { assignments, for } \\
\text { example preparing } \\
\text { a self-presentation } \\
\text { or preparation for a } \\
\text { job interview, } \\
\text { contributed to } \\
\text { active participation } \\
\text { and planning. } \\
\text { Individual sessions: } \\
\text { developing } \\
\text { vocational skills } \\
\text { and work routines, } \\
\text { enhancing self- } \\
\text { management skills, } \\
\text { providing work } \\
\text { placement } \\
\text { opportunities and } \\
\text { work experience, } \\
\text { and advising on } \\
\text { workplace } \\
\text { modifications. } \\
\end{array}$ & & & \\
\hline $\begin{array}{l}\text { Wang et al. } \\
2008\end{array}$ & $\begin{array}{l}\text { United } \\
\text { States of } \\
\text { America }\end{array}$ & Cohort & Diabetes & $14.0 \mathrm{yrs}$ & \begin{tabular}{|l|} 
Group \\
sessio \\
ns
\end{tabular} & Camp & $\begin{array}{l}\text { Physician, } \\
\text { medical } \\
\text { students, } \\
\text { and a } \\
\text { dietitian }\end{array}$ & $\begin{array}{l}\text { Camping } \\
\text { program }\end{array}$ & $\begin{array}{l}\text { Educational } \\
\text { sessions }\end{array}$ & $\mathrm{NA}$ & MM & NA \\
\hline $\begin{array}{l}\text { Wysocki et } \\
\text { al. } 2007\end{array}$ & \begin{tabular}{|l} 
United \\
States of \\
America
\end{tabular} & RCT & Diabetes & $14.0 \mathrm{yrs}$ & \begin{tabular}{|l|} 
Family \\
- \\
center \\
ed
\end{tabular} & Clinic & $\begin{array}{l}\text { Psycholog } \\
\text { ists }\end{array}$ & $\begin{array}{l}\text { Educational } \\
\text { and skills } \\
\text { training } \\
\text { sessions }\end{array}$ & $\begin{array}{l}\text { Problem solving } \\
\text { training, } \\
\text { communication } \\
\text { training, and } \\
\text { cognitive } \\
\text { restructuring and } \\
\text { functional- } \\
\text { structural family } \\
\text { therapy. Therapists } \\
\text { participated } \\
\text { actively, frequently } \\
\end{array}$ & $\begin{array}{l}12 \text { sessions over } 6 \\
\text { months attended }\end{array}$ & $\mathrm{MM}$ and $\mathrm{RM}$ & NA \\
\hline
\end{tabular}




\begin{tabular}{|c|c|c|c|c|c|c|c|c|c|c|c|c|}
\hline & & & & & & & & & \begin{tabular}{|l} 
providing \\
instructions, \\
feedback, \\
modeling, and \\
rehearsal. Also \\
homework was \\
given each \\
session.
\end{tabular} & & & \\
\hline $\begin{array}{l}\text { Xenakis et } \\
\text { al. } 2010\end{array}$ & \begin{tabular}{|l} 
United \\
States of \\
America
\end{tabular} & Cohort & \begin{tabular}{|l|} 
Physical \\
disabilities, \\
$93 \%$ \\
congenital
\end{tabular} & $14-21 \mathrm{yrs}$ & \begin{tabular}{|l} 
Individ \\
ualize \\
d and \\
group \\
sessio \\
ns
\end{tabular} & $\begin{array}{l}\text { Clinic / } \\
\text { Hospital } \\
\text { based } \\
\text { center }\end{array}$ & $\begin{array}{l}\text { A program } \\
\text { coordinato } \\
\text { r, } \\
\text { instructors } \\
\text { and tutors, } \\
\text { a care } \\
\text { assistant, } \\
\text { and } \\
\text { volunteers } \\
\text {. The } \\
\text { instructors } \\
\text {, experts } \\
\text { in their } \\
\text { chosen } \\
\text { fields, } \\
\text { have prior } \\
\text { experienc } \\
\text { e working } \\
\text { with } \\
\text { adolescen } \\
\text { ts and/or } \\
\text { persons } \\
\text { with } \\
\text { physical } \\
\text { disabilities }\end{array}$ & $\begin{array}{l}\text { Educational } \\
\text { sessions }\end{array}$ & $\begin{array}{l}\text { Discussions, } \\
\text { expressive arts, } \\
\text { goal-setting, field } \\
\text { trips (community } \\
\text { recreation and } \\
\text { learning } \\
\text { institutions). }\end{array}$ & $\begin{array}{l}12 \text { consecutive 21/2- } \\
\text { hour weekly } \\
\text { sessions }\end{array}$ & $\begin{array}{l}\text { MM, RM } \\
\text { and EM }\end{array}$ & NA \\
\hline $\begin{array}{l}\text { Yoon et al. } \\
2007\end{array}$ & \begin{tabular}{|l} 
United \\
States of \\
America
\end{tabular} & Cohort & \begin{tabular}{|l|} 
Sickle Cell \\
Disease
\end{tabular} & $10.7 \mathrm{yrs}$ & \begin{tabular}{|l} 
Individ \\
ualize \\
d
\end{tabular} & Clinic & NA & CD-ROM & $\begin{array}{l}\text { Game with } \\
\text { feedback }\end{array}$ & NA & $\overline{M M}$ & $\begin{array}{l}\text { Gaming } \\
\text { theory }\end{array}$ \\
\hline
\end{tabular}

*Abbreviations: NA=Not available (meaning this information couldn't be derived from the original research article); RCT=Randomized Controlled Trial; SM=Self-management; $\mathrm{MM}=$ Medical management; $\mathrm{RM}=$ Role management; $\mathrm{EM}=$ Emotion management 
Table A.2 Overview of outcome measures used in the evaluation studies*

\begin{tabular}{|c|c|c|}
\hline $\begin{array}{l}\text { Groups of } \\
\text { outcomes }\end{array}$ & Specific outcomes & References \\
\hline \multirow[t]{15}{*}{ Health outcomes } & $\begin{array}{l}\text { Clinical outcomes (e.g. blood glucose levels, peak expiratory flow rate or pulmonary } \\
\text { functioning, BMI, fatigue) }\end{array}$ & $\begin{array}{l}{[27,30,38,39,41,44-47,51-53,55-57,} \\
64,66,99,101]\end{array}$ \\
\hline & Number of (outpatient) clinic visits or disease-related emergency department visits & {$[35,39,44,64,105]$} \\
\hline & Hospitalizations (due to chronic condition) & [35] \\
\hline & $\begin{array}{l}\text { Frequency or intensity of disease-specific symptoms, i.e. morbidity (e.g. asthma } \\
\text { episodes or pain) }\end{array}$ & $\begin{array}{l}{[28-33,35,36,38,39,41-45,66,73-77} \\
83,91,93,96,100,105,109]\end{array}$ \\
\hline & $\begin{array}{l}\text { Activity limitations or functional or disease-related disability / perceived difficulty in } \\
\text { performing daily activities }\end{array}$ & {$[73,75,77,91,93-95]$} \\
\hline & Medication or treatment adherence or usage & $\begin{array}{l}{[31,34,35,38,41,44,46,55-57,64} \\
79,85,90,96,101]\end{array}$ \\
\hline & Self-perceived health status & [41] \\
\hline & Somatic awareness & [74] \\
\hline & Disease-specific coping (e.g. coping with pain during SCD-related pain episodes) & {$[95,105]$} \\
\hline & Functional health status / Physiologic health status / Physical functioning or activity & {$[64,66,74,81,94,99]$} \\
\hline & Condition-related disability & [100] \\
\hline & Goal status in individual health and wellness planning & {$[103]$} \\
\hline & General satisfaction with health & [40] \\
\hline & Condition-specific goals & [11] \\
\hline & Risk behavior (e.g. smoking) & [35] \\
\hline \multirow[t]{5}{*}{ Self-care } & Self-care behavior or practice & {$[39,44,46,110]$} \\
\hline & Disease-related skills & [65] \\
\hline & Independent health behavior (e.g. self-medication or independent consultations) & [98] \\
\hline & Motivation, knowledge, skills and abilities for self-care & [39] \\
\hline & Disease-related self-regulation & [33] \\
\hline \multirow[t]{4}{*}{ Self-efficacy } & Disease-related self-efficacy & $\begin{array}{l}{[28,32,39,44,46,51,55,59,63,64} \\
86,96,109]\end{array}$ \\
\hline & Self-efficacy related to managing interactions with healthcare providers & {$[105,86$} \\
\hline & General self-efficacy & {$[67,86]$} \\
\hline & Outcome expectations of disease-related self-management & [59] \\
\hline \multirow[t]{2}{*}{ Self-perception } & Confidence regarding disease-specific management & [108] \\
\hline & $\begin{array}{l}\text { Self-rated competence in the areas of (a) scholastic work, (b) social acceptance, (c) } \\
\text { athletic ability, (d) physical appearance, (e) behavioral conduct, and (f) global self-worth }\end{array}$ & [107] \\
\hline \multirow[t]{2}{*}{ Sense of control } & Sense or locus of control & {$[63,64]$} \\
\hline & Role mastery & [110] \\
\hline
\end{tabular}




\begin{tabular}{|c|c|c|}
\hline $\begin{array}{l}\text { Groups of } \\
\text { outcomes }\end{array}$ & Specific outcomes & References \\
\hline \multirow{6}{*}{$\begin{array}{l}\text { Psychological } \\
\text { outcomes }\end{array}$} & Depressive symptoms / depression & {$[51,56,61,71,74,75,78,93-95]$} \\
\hline & Anxiety or (dis)stress & {$[41,62,64,71,73,74,96]$} \\
\hline & Catastrophic thinking about the condition & {$[74]$} \\
\hline & Psychological symptoms & [89] \\
\hline & Self-esteem & {$[39,67,71]$} \\
\hline & Body image & [62] \\
\hline \multirow{3}{*}{$\begin{array}{l}\text { Psychosocial } \\
\text { functioning }\end{array}$} & Psychosocial adjustment & {$[29,81]$} \\
\hline & Developmental goals & {$[102]$} \\
\hline & Psychosocial functioning & {$[49,89,99]$} \\
\hline \multirow[t]{4}{*}{ Coping } & Coping or coping styles & {$[51,63,71]$} \\
\hline & Adaptive and maladaptive behaviors and emotions & [42] \\
\hline & Coping abilities/competencies and resourcefulness or coping styles & {$[40,42,44,82]$} \\
\hline & Internalizing and externalizing behavior & {$[61]$} \\
\hline \multirow{3}{*}{$\begin{array}{l}\text { Health-related } \\
\text { quality of life or } \\
\text { subjective } \\
\text { wellbeing }\end{array}$} & (Health-related) Quality of Life (generic) & {$[37,54,64,69,86,93,104]$} \\
\hline & Disease-specific health-related quality of life & \begin{tabular}{|l}
{$[27,28,30,32,33-36,42-44,46,47$,} \\
$51,55,56,59,61,63,76,93,96,98]$
\end{tabular} \\
\hline & Subjective wellbeing & {$[110]$} \\
\hline \multirow{6}{*}{$\begin{array}{l}\text { Vocational } \\
\text { participation }\end{array}$} & School functioning (absence/attendance or grades) & {$[35,43,66,73,74,105,107,109]$} \\
\hline & Academic performance & {$[43]$} \\
\hline & Occupational performance / work participation & {$[104]$} \\
\hline & Pre-vocational experience & {$[98]$} \\
\hline & Social and academic activities competencies & [61] \\
\hline & Occupational problems & {$[102,104]$} \\
\hline \multirow[t]{12}{*}{ Social participation } & Challenges / problematic situations encountered in different life areas & {$[70,82]$} \\
\hline & Days of changed plans & [35] \\
\hline & Physical, emotional and behavioral concerns related to certain life areas & {$[62]$} \\
\hline & (Autonomy in) participation in several life areas (e.g., living and romantic relationships) & {$[67,72,109]$} \\
\hline & (Influence on) daily life with the condition & {$[47,86]$} \\
\hline & Social skills & {$[61,92,112]$} \\
\hline & Social goals / goal attainment & {$[111,112]$} \\
\hline & Social acceptance by peers & {$[112]$} \\
\hline & Dating & {$[62]$} \\
\hline & Independence & [112] \\
\hline & Parent involvement in diabetes care & {$[54]$} \\
\hline & Family functioning & [51] \\
\hline
\end{tabular}




\begin{tabular}{|c|c|c|}
\hline $\begin{array}{l}\text { Groups of } \\
\text { outcomes }\end{array}$ & Specific outcomes & References \\
\hline $\begin{array}{l}\text { Family involvement } \\
\text { or conflict (related } \\
\text { to disease-related } \\
\text { management tasks) }\end{array}$ & $\begin{array}{l}\text { Division/sharing of responsibility, conflict or interaction within families related to disease } \\
\text { specific tasks (e.g. blood glucose monitoring or insulin injections) }\end{array}$ & {$[46,54,57,60,85,111,112]$} \\
\hline \multirow[t]{2}{*}{ Support by others } & Perceived support & [80] \\
\hline & Social support by family and friends & [89] \\
\hline \multirow[t]{3}{*}{$\begin{array}{l}\text { Others (not } \\
\text { included in groups) }\end{array}$} & Knowledge of the disease and/or treatment & $\begin{array}{l}{[28,32,34,36-39,44,49,53,62-64,} \\
79,82,90,92,96,98,105,107,108, \\
111]\end{array}$ \\
\hline & Attitudes towards illness & {$[27,78,79,86]$} \\
\hline & Problem solving & {$[37,78]$} \\
\hline
\end{tabular}

